\title{
Vurdering av filleristing av barn i straffesaker for norske domstoler
}

Ulf Stridbeck, Aslak Syse, Pelle Nilsson, Johan Wikström og Knut Wester

Ulf Stridbeck, fil.kand., Universitetet i Göteborg (1981), jur.kand. Lunds Universitet (1981), juris dr., Lunds Universitet (1992). Siden 1997 professor dr. juris ved Universitetet i Oslo, fra 2020 emeritus samme sted. E-post:

ulf.stridbeck@jus.uio.no

Aslak Syse, cand.med. (1972), cand.jur. (1988) og dr. juris (1996). Han har arbeidet i legestillinger i Finnmark i perioden 1972-1988. Fra 1989 har han vært tilknyttet Institutt for offentlig rett ved Universitetet i Oslo, i tidsrommet 1997-2016 som professor, fra 2017 emeritus samme sted. E-post: aslak.syse@jus.uio.no

Pelle Nilsson, Med. Dr. (1994), Uppsala Universitet. Han er spesialist i neurokirurgi (1999), overlege ved neurokirurgen, Kliniken för neurofysiologi, neurokirurgi och neurologi, Akademiska sjukhuset med ansvar for barneneurokirurgi siden 2005. E-post: pelle.nilsson@neuro.uu.se

Johan Wikström, Med. Dr. (2001), Uppsala universitet. Han er spesialist i medisinsk radiologi (1997) og neuroradiologi (2002), overlege ved Bild- och funktionsmedicinskt centrum, Röntgenavdelningen, Akademiska sjukhuset siden 2002 og professor i neuroradiologi vid Uppsala universitet (Inst för kirurgiska vetenskaper, enheten för radiologi) siden 2018. E-post: Johan.Wikstrom@radiol.uu.se

Knut Wester, cand. med. (1965), dr. med. UiO (1974). Overlege/avdelingsoverlege i nevrokirurgi ved Haukeland Universitetssjukehus siden 1986 og professor ved Det medisinske fakultet, Universitetet i Bergen siden 1989. Nå professor emeritus. President i «Scandinavian Neurotrauma Committee», som lager de nordiske retningslinjene for håndtering av hodeskadepasienter, siden 2013. E-post: knut.wester@gmail.com

\section{Sammendrag}

Dette er en flerfaglig gjennomgang av samtlige norske straffesaker funnet på Lovdata fra 2004 fram til 2015 om «filleristing». Hver sak er gjennomgått av forfatterne; to jurister og tre medisinske eksperter på hodeskader hos barn. Materialet har bestått av straffesaksdokumentene, inkludert sakkyndige rapporter og aktuelle pasientjournaler med billeddiagnostikk av de samme barna. Rettssakene presenteres ut fra dommene, og i de aktuelle sakene er rettens vurderinger i mange saker knyttet opp mot de rettssakkyndiges vurderinger. Parallelt har de medisinske forfatterne etterprøvd hvorvidt de sakkyndiges vurderinger står seg ut fra dagens kunnskap om slike skadebilder. Særlig vekt er lagt på muligheten for at skadebildet ikke er påført ved foreldres eller andres voldsbruk, men av medisinske tilstander hos barnet selv. Det kan synes som om det er få fellende straffedommer som utelukkende er basert på sakkyndighetsvurderinger vedrørende filleristing. I flere andre saker synes det å foreligge tvil når det gjelder skadeårsak og skadepåføring. I tillegg presenteres enkelte barnevernssaker med vekt på beviskravet ved filleristing sammenliknet med straffesakene, men her uten å ha foretatt nye medisinske vurderinger.

\section{Nøkkelord}

SBS, AHT, sakkyndighet, filleristing, barnemishandling, vold mot barn 


\section{Tema og problemstilling}

\subsection{Innledning}

Temaet for vår artikkel er hvordan saker om «filleristing» av barn er blitt vurdert av norske domstoler. ${ }^{1}$ Som regel sikter filleristing til en handling der en person rister et annet menneske, stort sett et spedbarn, fram og tilbake. Sentralt i vurderingen om filleristing har forekommet, er om barnet har tre spesifikke skader; (1) hjerneblødning utenpå hjernen under den harde hjernehinnen (subdural blødning), (2) blødninger inne i øynene (netthinneblødning) og (3) tegn til skader på hjernevev. Disse tre kjennetegnene benevnes «triaden». ${ }^{2}$

En av de tidlige filleristingssakene i Norge, før «triaden» var etablert som diagnoseinstrument i Norge, er den såkalte Rødseth-saken fra $1981 .{ }^{3}$ Sveinung Rødseth ble pågrepet og fengslet $\mathrm{i}$ forbindelse med mistanke om å ha mishandlet sin datter slik at hun senere døde. Dødsårsaken var «blødning under hjernehinnen». I tillegg hadde hun et brukket bein og flere blåmerker. Han ble domfelt for, ved to tilfeller, å ha mishandlet sin datter, som ved hendelsene var henholdsvis tre og fem måneder gammel. Ifølge faktumbeskrivelsen i dommen hadde han ved den første anledningen kastet barnet fra seg i en seng slik at beina traff sengekanten med den følge at begge beina hovnet opp og høyre skinnebein ble brukket. To måneder senere kastet eller støtte han barnet mot vuggen eller mot en vegg eller annet inventar i soverommet slik at hun ble påført hodeskader, som ledet til døden etter noen dagers forløp. Han ble domfelt for barnemishandling med døden til følge, strl. $1902 \S 219$ første og annet straffalternativ, til ett år og ni måneders fengsel. ${ }^{4}$

Etter at to tidligere gjenopptakelsesbegjæringer ble forkastet, hadde en av de sakkyndige fra 1982 gitt uttrykk for tvil og to senere oppnevnte sakkyndige nyansert vurderingene vedrørende mulig sykdom som kunne ha forsterket virkningene av ytre påkjenninger i betydelig grad. Det kom fram at datteren sannsynligvis led av osteogenesis imperfecta type IV (beinskjørhet). ${ }^{5}$ I en «fagfellevurdering» av den sakkyndiges vurdering skriver fire eksperter: «Foreldre til barn med osteogenesis imperfecta ble ofte uskyldig mistenkt for barnemishandling». ${ }^{6}$ Etter denne tredje gjenåpningsbegjæring ble Rødseth frifunnet. I den frifinnende dommen vises til foreliggende usikkerhet vedrørende barnets sjukdom/skader. I tillegg kritiseres politiets avhør som frambragte en falsk tilståelse fra Rødseth. ${ }^{7}$ Det ble nemlig dokumentert at Rødseth ikke var hjemme den kvelden datterens skade oppsto.

\footnotetext{
${ }^{1}$ Filleristing har på norsk flere synonymer, blant annet fordi det skjer i situasjoner der barnet tilsynelatende skriker ustoppelig, blir handlingen også kalt «ti-stille-syndrom». I straffedommene anvendes de forskjellige begrepene - filleristing, shaken baby syndrom, shaken-impact syndrome, abusive head trauma og ti-stillesyndrom - som synonymer. Det er som nevnt ikke alltid at skillet mellom handlingen (filleristingen), og skadefølgen «shaken baby syndrom» (SBS) er klar, se f.eks. LA-2006-165987, LB-2007-81085, LH-2008160684 og LH-2010-96312. Dette skillet tydeliggjøres heller ikke i denne artikkelen idet vi bruker filleristing og SBS som synonymer.

Det er like fullt tenkelig at noen blir filleristet uten at det resulterer i SBS eller andre alvorlige skadefølger. Men da vil det som regel verken bli reist barnevernssak for fylkesnemnda eller straffesak mot utøveren. Noen skader har andre årsaker enn filleristing, f.eks. kan skaden ha skjedd i samband med fødsel, eller ved fall mot hardt underlag eller ved at sykdom eller andre medisinske tilstander hos babyen er oversett.

På svensk anvendes begrepet «skakvåld». Ifølge våre kontakter i Danmark har man ikke problematisert SBSdiagnosen spesielt. Det foreligger på dette området en rekke underrettsdommer for «ruskevold».

${ }^{2}$ For en historikk over diagnostiseringen av SBS/AHT se M.B. Johnson, C. Baker, B. Prempeh og S.R. Lewis, Shaken Baby Syndrome/Abusive Head Trauma: Wrongful Conviction Risks, Mis-information Effects, and Psychological Consultation, Journal of Forensic Psychology Research and Practice, 20:3, s. 290-304, DOI: 10.1080/24732850.2020.1726165.

${ }^{3}$ A. I. Aure, Gjenopptakelse til gunst for siktede, generelt og sett i relasjon til Rødsethsaken, upublisert særavhandling til 5. avd., høst 1993, Juridisk fakultet, Universitetet i Oslo.

${ }^{4}$ Rt-1982-718. I Frostating lagmannsrett fikk han to år og seks måneders fengsel som straff.

${ }^{5}$ Sykdommen gir forskjellige utslag etter individuell alvorlighetsgrad, men $\varnothing \mathrm{kt}$ bruddtendens, bloduttredelser og blå flekker er svært vanlig. Aure (1993), s. 29.

${ }^{6}$ Et utvalg med fire medisinere ble satt ned for å vurdere den sakkyndige dr. Colin R. Patersons arbeider og konklusjoner på feltet beinskjørhet. De hadde ikke noen vektige innvendinger mot hans arbeider. Sitert fra LF1996-518.

${ }^{7}$ LF-1997-353.
} 
I tilknytting Rødseth-saken ble det laget et TV-program med tittelen «Sjuk eller mishandla». ${ }^{8}$ Vektleggingen av mistanke om mishandling førte til Rødseths uriktige tilståelse. Senere viste det seg, som nevnt, at datterens beinskjørhet (beinbruddet) og blødersyke (blødningen under den harde hjernehinnen) forklarte skadene. «Sjuk eller mishandla» kunne slik sett også vært en underoverskrift på denne artikkelen, idet det nettopp er en slik problemstilling som analyseres i det følgende.

Filleristing av spedbarn er antatt å kunne medføre alvorlige konsekvenser fordi hodet hos disse barna er svært tungt i forhold til resten av kroppen og fordi disse barna har svak nakkemuskulatur. Som det kommer til uttrykk i en tingrettsdom: «Dersom ein baby blir rista kraftig, vil hjernen, som er mindre enn skallen, utsettes for akselerasjon og deselerasjon (bråstopp)» (THEDM-2015-16342).

Et mer eller mindre synonymt ord for både handlingen og det mulige utfallet er «shaken baby syndrome» (SBS) som er brukt i engelskspråklig litteratur. ${ }^{9}$ Vi vil stort sett benytte filleristing og SBS som synonymer i det videre. I denne sammenhengen er dette synonymer som omfatter både aktiviteten og den eventuelle skadefølgen, selv om det også er mulig å skille mellom handling og resultat. I de aktuelle straffesakene som skal behandles, gjennomføres som regel ikke et slikt skille så vår språkbruk er i tråd med betegnelsene i rettspraksis.

De i litteraturen angitte kjennetegnene ved SBS hos spedbarn er blødninger mellom hjernen og skallens innside (i subduralrommet) og øynene, samt tegn til skader i hjernevevet. I tillegg finner man på de aller fleste babyer som har vært utsatt for kraftig risting eller annen voldsbruk, også blåmerker og brudd, samt slagskader mot hodet.

På politiets hjemmesider er det i løpet av de siste årene vært fokusert på mulige hodeskader ved mishandling og vold mot barn. ${ }^{10}$ Flere skader skyldes stump vold. Ifølge informasjonen fra politiet kan kraftig risting føre til «shaken baby syndrome». Det oppfordres til at nybakte foreldre skal advares mot at barnet blir kraftig ristet. På politiets hjemmesider framheves:

De vanligste skadene ved mishandling og vold mot barn, skyldes stump vold. Det vil si at barnet enten blir slått, sparket, kløpet eller grepet, slengt eller ristet. Dette kan gi skader som blåmerker, bløtdelsskader, brudd og indre blødninger. Kraftig risting kan føre til shaken baby syndrome.

Alvorlig og dødelig mishandling rammer oftest spedbarn. Det dreier seg ofte om vold mot hodet. Har et barn under ett år en alvorlig skade, er det mest sannsynlig at volden er påført av andre.

Vold mot små barn skjer ofte i affekt. Det vil si at utøveren av volden handler under sterke følelser. Det kan skje når en omsorgsperson av forskjellige grunner ikke klarer å håndtere at barnet gråter eller er urolig. Vedkommende utsetter barnet for vold. Ofte vet ikke utøveren om de alvorlige skadene volden fører til. Vold og mishandling kan også bli brukt for å oppdra barnet. (uthevelsen på politiets hjemmesider.)

Karakteristisk for skadefølgen ved filleristingen er at denne kan oppstå i løpet av få sekunder. I mange situasjoner skyldes ristingen frustrasjon hos gjerningspersonen uten at vedkommende har et egentlig $\emptyset n s k e$ om å skade barnet, jf. betegnelsen «ti-stille-syndrom». Det legges i flere av våre straffesaker til grunn at gjerningspersonen ikke har noen egentlig forståelse av hvor farlig slik filleristing kan være, jf. HR-2017-2282-A avsnitt 26.

\footnotetext{
${ }^{8}$ NRK, 10. januar 1990.

${ }^{9}$ I tillegg til shaken baby syndrome (SBS), brukes «Abusive Head Trauma» (AHT), hvilket sikter til at det er en mishandlingsbetinget hodeskade. Videre i litteraturen er anvendt «Nonaccidental head trauma/injury» (NAI, NAT) og «Intentional head trauma/injury» (IHT, IHI).

${ }^{10} \mathrm{Se}$ : https://www.politiet.no/rad/vold-i-nare-relasjoner/mistenker-du-vold-mot-barn/
} 
Saker om filleristing er blitt behandlet ved domstoler rundt om i verden. ${ }^{11}$ Dette har skjedd parallelt med at det har oppstått en medisinsk debatt vedrørende diagnostiseringen av SBS. ${ }^{12}$ Dette gjelder særlig spørsmålet om den bevismessige verdien av den førnevnte triaden.

Tvil om den sterke koblingen mellom triaden og filleristing begynte å vokse fram i Sverige i 2012. På internasjonale konferanser i 2012 og 2013 ble det reist spørsmål om triadens diagnostiske betydning, det vil si den da etablerte koblingen mellom triaden (som skadefølge) og filleristing (som skadeårsak). I denne perioden avgjorde den svenske Högsta domstolen (HD) to SBS-saker.

En sak fra 2013 gjaldt en mann som var blitt domfelt for «skakvåld» til en dom på fem års fengsel. ${ }^{13}$ Han begjærte gjenåpning. Med blant annet nye sakkyndigrapporter, støtte fra både Rättsliga rådet og fra den svenske riksadvokaten ble saken tatt opp til ny vurdering. Rättsliga rådet viser til en utredning fra en sakkyndig i Socialstyrelsen som skriver:

Under en lång följd av år var den dominerande vetenskapliga uppfattningen beträffande blödningar mellan hjärnans hinnor och i viss mån skador i hjärnvävnaden [att de] innebar en stark misstanke att skadorna var uppkomna till följd av skakvåld och framförallt om man även kunde iaktta blödningar i näthinnorna, s.k. retinala blödningar. Den vetenskapliga utvecklingen har inneburit att det $[. .$.$] efter hand har publicerats ett antal vetenskapliga arbeten där man ansett sig kunna påvisa$ andra uppkomstsätt för blödningar av detta slag. Även om antalet barn i de vetenskapliga studier där man anser sig påvisa sjukdom/naturliga orsaker såsom bakomliggande faktor är begränsade kan man i dag inte längre bortse från möjligheten av att blödningar mellan hjärnhinnorna och skador i hjärnan av detta slag kan ha andra uppkomstsätt än yttre våld/skakning. ${ }^{14}$

Den svenske riksadvokaten skriver «att den vetenskapliga utvecklingen har manat till större försiktighet vid bedömningen av skador av den sort som är aktuella i målet». ${ }^{15}$ Videre konstateres «att den stabila grund på vilken de tidigare domarna vilade idag framstår som mer osäker». ${ }^{16}$ Etter dette besluttet HD at saken skulle gjenåpnes. ${ }^{17}$

I en annen sak om filleristing frifant HD tiltalte. ${ }^{18}$ En mann ble domfelt av Hovrätten for Västra Sverige til fengsel i ett år og seks måneder for grov legemsbeskadigelse. ${ }^{19}$ Domfelte anket dommen, men riksadvokaten motsatte seg at dommen skulle endres. Om å trekke slutninger fra skade til gjerningsmann skriver HD: «Den typ av bevisning som det här är fråga om, och som innebär att säkra slutsatser beträffande ett påstått handlande ska kunna dras enbart av att vissa effekter har uppstått, måste bedömas med mycket stor försiktighet.» ${ }^{20}$ Det interessante i HDs frifinnende dom er konstateringen «att det vetenskapliga stödet för diagnosen skakvåld allmänt sett har visat sig vara osäkert». ${ }^{21}$ Det framheves i avgjørelsen:

${ }^{11}$ En av de tidligste sakene der ordet filleristing av barn i Norge er nevnt, er fra 1999. Den var svært alvorlig ved at den tre måneder gamle datteren døde av skadene påført av foreldrene. Lagmannsretten (LG-2001-1560) fant det bevist at barnet var påført flere hodeskader, et dusin beinbrudd lokalisert til ribbein, armer og bein. Flertallet fant det bevist at begge foreldrene hadde ristet jenta kraftig i tiden forut for at hun døde. Bruddene i venstre lårbein og i høyre fot kunne ikke forklares med kraftig risting av barnet. Begge foreldrene ble dømt til fire års fengsel. Anke til Høyesterett ble nektet fremmet.

${ }^{12}$ Se for eksempel E. B. Zakirova, «Shaken Baby Syndrome: as a Controversy in Wrongful Conviction Cases», Albany Law Review, vol. 81, no. 3, 2018 s. 1027-1046, N. Lynøe, G. Elinder, B. Hallberg et al., «Insufficient evidence for 'shaken baby syndrome' - a systematic review», Acta Paediatr., vol. 106, 2017 s. 1021-1027. Se også C. Brook, «Is there an evidentiary basis for shaken baby syndrome? The conviction of Joby Rowe», Australian Journal of Forensic Sciences, 2019. https://doi.org/10.1080/00450618.2019.1626483

13 Ö 1860-12.

${ }^{14}$ Ibid., avsnitt 20.

${ }^{15}$ Ibid., avsnitt 22.

${ }^{16}$ Ibid.

${ }^{17}$ Det er ikke kjent at den norske Gjenopptakelseskommisjonen har behandlet saker om filleristing.

${ }^{18}$ NJA 2014, s. 699.

${ }^{19} \mathrm{Ibid}$.

${ }^{20}$ Ibid., avsnitt 18.

${ }^{21}$ Ibid., avsnitt 21. 
För att det av endast det förhållandet, att vissa kroppsskador föreligger, ska kunna vara ställt utom rimligt tvivel att dessa har orsakats av någon på ett visst angivet brottsligt sätt, måste krävas att slutsatsen vilar på en vetenskaplig ståndpunkt som det finns mycket starka belägg för. Samtidigt måste det vara i praktiken uteslutet att det finns någon annan tänkbar förklaring till skadorna. ${ }^{22}$

I denne saken hadde barnet tidligere vært rammet av RS-virus, og det fantes spor av en eldre blødning under den harde hjernehinnen. Barnets symptomer og medisinske funn kunne således skyldes andre årsaker enn filleristing.

Debatten og HDs avgjørelser førte til at man i Sverige ønsket en granskning av vitenskapen bak SBS. Oppdraget gikk til Statens beredning för medisinsk och social utvärdering (SBU) som leverte en kunnskapsoversikt i 2016 som satte spørsmålstegn ved robustheten ved SBS-diagnostiseringen. ${ }^{23}$

Uriktige, ufullstendige eller sakkyndighetsrapporter som ikke er vitenskapelig oppdaterte kan få alvorlige rettslige følger. ${ }^{24}$ Dette er for $\emptyset$ vrig et generelt problem som gjelder sakkyndiges rolle i rettssaker. Sakkyndighetsbevis er som regel vanskelig å overprøve av retten. Dersom det ikke finnes andre bevis i saken og domstolene lener seg mot de sakkyndige uten at deres vurderinger er riktige, kan dette føre til uriktige domfellelser. Veien er således kort fra uriktig diagnostisering til uriktig dom - fellende eller friende.

\subsection{SBS - medisinsk beskrivelse og mulige årsaker}

Den klassiske triaden for SBS er som nevnt subdural blødning (blødning under den harde hjernehinnen), blødninger i øyenbunnen og tegn til skader på hjernevev. Det legges til grunn av forsvarerne av triaden som «diagnostisk bevis» for SBS at disse funnene vil oppstå når barnets kropp holdes og hodet ristes fram og tilbake. ${ }^{25}$ Skadene antas da å oppstå ved akselerasjon/deselerasjon.

Ved symptomer/funn i triaden må man samtidig undersøke om disse kan ha en annen årsak enn risting. ${ }^{26}$ Som ellers ved god etterforskning må det oppstilles alternative hypoteser. Funn som subdurale blødninger, øyeblødninger og skader av hjernevev er beskrevet etter fødsel og ved forskjellige sykdomstilstander som krampeanfall, blødningsforstyrrelser, smittsomme sykdommer, metabolske sykdommer, immunologiske lidelser, skjelettsykdommer og blodåremisdannelser. ${ }^{27}$ I vårt materiale er det lagt særlig vekt på en vurdering av om eventuelle blødninger og hjerneskader kan ha skyldtes tilstanden Benign Ekstern Hydrocefalus (BEH) - på norsk: godartet utvendig vannhode - og ikke SBS eller traumer direkte mot hodet. Det at tilstanden BEH kalles benign (godartet) kan være misvisende, idet den disponerer for til dels alvorlige komplikasjoner som blødninger i subduralrommet (spalterommet mellom de to ytterste hjerne- og ryggmargshinnene). Slike subdurale blødninger antas også, som nevnt, å være ett av kardinalfunnene ved filleristing. BEH kan derfor noen ganger bli - og har blitt - feildiagnostisert som SBS. ${ }^{28}$

Helt fra fosterlivet produserer hjernen væske (cerebrospinalvæske - CSF) i de naturlig forekommende hulrommene i hjernen. Voksne personer produserer ca. 0,5 liter per døgn, spedbarn mindre enn én desiliter. Denne væsken fjernes fra det intrakranielle rom ved biologisk

\footnotetext{
${ }^{22}$ Ibid., avsnitt 21.

${ }^{23}$ Statens beredning för medisinsk och social utvärdering (SBU) Rapport 255/2016. Skakvåld. Triadens roll vid medicinsk utredning av misstänkt skakvåld. En systematisk översikt (SBU).

${ }^{24} \mathrm{C}$. E. White, «'I did not hurt him ...this is a nightmare': The introduction of false, but not fabricated, forensic evidence in police interrogations», Wisconsin Law Review, 2015, s. 941-973, D. Tuerkheimer, «The next innocence project: Shaken baby syndrome and the criminal courts», Washington University Law Review, vol. 87, 2009, s. 1-58, K. A. Findley, D. Johnson, K. Judson, M. Staas, D. Redleaf og C. J. Hyman, «Shaken Baby Syndrome/Abusive Head Trauma: A Complicated Child Welfare Issue», The Guardian 1 June 2015, 37, Univ. of Wisconsin Legal Studies Research Paper No. 1358. Tilgjengelig på SSRN: https://ssrn.com/abstract=2627324, R. Burg, «Un-Convicting the innocent: The case for shaken baby syndrome review panels», University of Michigan Journal of Law Reform, vol. 45, 2012 s. 657-694.

${ }^{25}$ B. Harding, R. A. Risdon og H. F. Krous, «Pathological diagnosis rests on the combined triad, not on individual injuries», BMJ, 328, 2004 s. 720.

${ }^{26}$ A. Stray-Pedersen og T. O. Rognum, «Shaken Baby Syndrome: Commentary on current debate», Scand J of Forensic Science, No. 2, 2006, s. 79-83.

${ }^{27}$ SBU s. 12.

${ }^{28} \mathrm{~K}$. Wester, «Two infant boys misdiagnosed as 'shaken baby', and their twin sisters: A Cautionary Tale», Pediatr Neurol, vol. 97, 2019 s. 3-11.
} 
filtrasjon tilbake til blodårer utenpå hjernen, vanligvis i takt med produksjonen av væsken. Dersom noe hindrer denne dreneringen av væske, hoper CSF seg opp i hodet. Dette fører til «vannhode» eller hydrocefalus og en raskere vekst av hodeomkretsen enn normalt. Tilstanden oppdages vanligvis ved rutinemålinger på helsestasjonen og/eller ved kliniske symptomer som for eksempel forsinket psykomotorisk utvikling eller epileptiske kramper. Ved den vanligste formen av hydrocefalus hoper vannet seg opp inne i hjernehulrommene, slik at hjernen «blåses opp» som en ballong, men noen ganger strømmer væsken uhindret ut av hjernen og hoper seg opp i væskerommet mellom hjerneoverflaten og skallens innside, i det «subdurale rom», noe som fører til «ekstern hydrocefalus» (BEH).

I Norge fødes det ca. 25 barn med BEH hvert år. ${ }^{29}$ Disse barna er født med normalt stort hode, men det begynner å vokse raskere enn normalt i løpet av de første levemånedene; de fleste har utviklet en klinisk BEH i løpet av tre-fire måneder. ${ }^{30}$ Det er omdiskutert om denne tilstanden bør behandles operativt ved å drenere overskudd av hjernevæske ut av kraniet, for eksempel til bukhulen ved en «shunt»operasjon.

\section{Materiale og metode}

En forutsetning for denne studien var å få tilgang til vanligvis taushetsbelagt medisinsk informasjon fra aktuelle helseinstitusjoner for å kunne «se bak» de aktuelle straffedommene. Da måtte samtidig straffesakene av-anonymiseres fra slik de er publisert på Lovdata. ${ }^{31}$

\subsection{Domsunders $\varnothing$ kelsen}

Vi har, etter søk på begrepene «filleristing» og «shaken baby syndrome» på Lovdata, funnet til sammen 24 rettssaker som gjelder barn. Utvalget på Lovdata er imidlertid begrenset på den måten at ikke alle, men stort sett de fleste lagmannsrettsdommer, ligger der. Utvalget av tingrettsdommer er sterkt begrenset. Det fører med seg at vi ikke har fått med oss samtlige strafferettsavgjørelser om «filleristing»/«shaken baby». På den annen side er sannsynligheten stor for at fellende dommer i tingretten har blitt anket til lagmannsretten og derfor er med i utvalget. Siden «filleristing»-sakene som regel gjelder bevisspørsmål under skyldspørsmålet, er meget få saker behandlet av Høyesterett. Av de 24 sakene vi har funnet, var 17 straffesaker og to var saker om tiltak etter barnevernsloven samt enkelte saker der dette ikke var et aktuelt tema. Vårt hovedmateriale omfatter samtlige publiserte straffesaker på Lovdata fra 2004 til 2015, se punkt $4 .{ }^{32}$ Dette utgjør 17 saker der vi har hatt tilgang til både de rettslige dokumentene og all nødvendig medisinsk informasjon, inkludert utført billeddiagnostikk. For én av de to sakene som er behandlet av Høyesterett, har vi bare dommene, se punkt 4.1. Vi peker i punkt 5 på enkelte generelle trekk ved bevisvurderingen i våre barnevernssaker. Vi avrunder med noen oppsummerende vurderinger i punkt 6 , både fra rettslig og medisinsk synsvinkel.

De interessante rettslige drøftingene vedrørende sakkyndighetsbevisene er gitt i underrettsdommene. De fleste sakene ble endelig avgjort i lagmannsretten, med en klar overvekt for Borgarting lagmannsrett (sju saker). Én sak ble endelig avgjort i tingretten.

I barnevernssaker kan en vurdering av foreliggende filleristing føre til svært inngripende tiltak overfor foreldrene, som regel initiert med en rask omsorgsovertakelse for å beskytte barnet mot eventuell fortsatt skadepåføring. Vårt materiale viser kun et utsnitt av denne sakstypen fordi barnevernssaker i første instans behandles og avgjøres av Fylkesnemnda for barnevern og sosiale saker, og ikke av domstolene. I en av barnevernssakene vi refererer, ble det gitt samtykke til tvangsadopsjon på grunn av sannsynliggjort mishandling mens straffesaken endte med frifinnelse. Dette kan forklares med det ulike beviskravet i de to sakstypene, se nærmere punkt 5 .

${ }^{29}$ U. S. Wiig, S. M. Zahl, A. Egge, E. Helseth og K. Wester, «Epidemiology of Benign External Hydrocephalus in Norway - A Population-Based Study», Pediatr Neurol. 2017 Aug; 73, s. 36-41. doi: 10.1016/j.pediatrneurol.2017.04.018. Epub 2017 Apr 24.

${ }^{30}$ S. M. Zahl, A. Egge, E. Helseth og K. Wester, «Clinical, radiological and demographic details of benign external hydrocephalus - a population-based study», Pediatr Neurol. 2019 Jan 30. pii: S0887-8994(18)31246-3. doi: 10.1016/j.pediatrneurol.2019.01.015

${ }^{31}$ Tillatelser til dette fikk vi fra henholdsvis NEM (Den nasjonale forskningsetiske komité for medisin og helsefag) og Riksadvokaten, se nedenfor.

${ }^{32}$ Det finnes avgjørelser fra eldre dato der små barn har blitt «ristet» uten at begrepet filleristet er brukt, for eksempel Rt-1973-911 og Rt-1982-718. Rettsutviklingen i nyere tid har vært preget av en noe strengere bedømmelse av vold, ikke minst i nære relasjoner, og at sakkyndigkompetansen har utviklet seg. Vårt utvalg begrenser seg derfor til «nyere tid», dvs. 2004-2015. 
$\AA$ «filleriste» et barn slik at det blir påført skader, er straffbart etter flere bestemmelser i straffeloven (1902/2005). De fleste straffesakene i vårt materiale er pådømt etter straffeloven av 1902 (strl. 1902). De bestemmelser som er blitt vist til, er strl. $1902 \S 219$ (vold og mishandling av slektning i rett oppog nedstigende linje), § 228 (legemsfornærmelse med skadefølge), § 229 første straffalternativ (legemsskade), § 229 andre og tredje straffalternativ (straffeskjerping ut fra skadefølge), § 232 (legemsskade påført på særlig smertefull måte mv.), § 233 (drap), § 238 (uaktsom legemsskade) og $\S 242$ (hensette/forlate en person i hjelpeløs tilstand). Tilsvarende bestemmelser finnes i dagens straffelov (strl. 2005) §§ 271, 272, 274, 275, 280, 282 og 288.

De to juristene (US og AS) har gjennomgått alle de aktuelle sakene med utgangspunkt i bevisvurderingen slik den framgår av dommene og spørsmål vedrørende straffutmåling. I hovedsak refererer vi til hva som ble lagt til grunn ved domsavsigelsene. Parallelt med denne rent rettslige gjennomgangen har tre medisinske eksperter med spesiell kompetanse i å vurdere hode/hjerneskader hos barn (neuroradiologi, barneneurokirurgi og generell neurokirurgi), gjennomgått de underliggende medisinske fakta fra sykehusjournaler med tilhørende røntgen- og mer moderne billeddiagnostikk.

Den valgte arbeidsmetoden har krevd en rekke tillatelser. Riksadvokaten tillot de to juristene å innhente aktuelle politidokumenter i straffesakene. ${ }^{33}$ Dette muliggjorde en nærmere vurdering av etterforskning og sakkyndighetserklæringer for å utdype grunnlaget for den avsagte domfellelsen eller frikjennelsen. Samtidig førte dette til identifisering av de aktuelle barna. Dette ga derved mulighet for å kunne innhente medisinsk informasjon fra de aktuelle sykehusene.

For å innhente medisinske journaler, røntgenbilder og annet materiale fra aktuelle sykehusavdelinger krevdes tillatelse fra Den nasjonale forskningsetiske komité for medisin og helsefag (NEM). ${ }^{34}$ Det viste seg like fullt å ta lang tid å få utlevert denne dokumentasjonen, dels fordi travle medisinske institusjoner ikke prioriterte slikt arbeid, dels fordi noen avdelinger, slik vi oppfattet det, aktivt motsatte seg å levere ut den etterspurte dokumentasjon slik at NEM etter klage måtte pålegge slik utlevering.

\subsection{Medisinsk tilnærming og metode}

Et av utgangspunktene for vår undersøkelse har vært å vurdere om det på dette feltet er blitt avsagt straffedommer på tvilsomt eller uriktig grunnlag. De to juristene har ikke kompetanse til, og derved ikke faglig mulighet for, å vurdere utfallet av de medisinske vurderingene. Denne artikkelen er altså en flerfaglig og ikke en tverrfaglig artikkel. Det vil gå tydelig fram hvor de medisinske ekspertene har ansvaret for de foretatte vurderingene gjennom egne avsnitt i hovedteksten som de to juristene har ansvaret for.

De medisinske forfatterne (PN, JW og KW) har medisinsk spesialkompetanse på feltet hode- og hjerneskader, men ikke spesiell kompetanse på andre skader. Spedbarn som bare hadde (ekstrakraniale) skader på kroppen (brudd etc.) inngikk derfor ikke i studien og ble ikke vurdert av dem. Vi mottok tilstrekkelig medisinsk dokumentasjon for i alt 17 barn med hode/hjerneskader som presenteres i punkt 4 der rettslige og medisinske vurderinger er sammenstilt.

De medisinske fakta har i straffesakene dannet bakgrunn for de sakkyndiges vurderinger og deres bidrag inn i straffesakene. I vår studie har de tre ekspertene vurdert de medisinske fakta uten først å kjenne til de sakkyndiges vurderinger i den enkelte sak, og heller ikke ble de under arbeidet gjort kjent med utfallet av straffesaken.

Som nevnt i punkt 1 er det blant annet reist spørsmål om de rettslig sakkyndige kan ha oversett en eventuell mulighet for at blødning og hjerneskade kan ha skyldtes benign ekstern hydrocefalus (BEH) eller andre ikke-traumerelaterte tilstander. Dette har ligget til grunn for den medisinske gjennomgangen av journaler og røntgenbilder. Dette spørsmålet blir derfor fortløpende kommentert under gjennomgangen av straffesakene i punkt $4 .{ }^{35}$

\footnotetext{
${ }^{33}$ RA 2016/01289-004 AGR/ggr 639.2, formidlet i brev av 19. september 2016.

${ }^{34}$ Bakgrunnen for at tillatelse ble gitt av NEM, i brev av 19. desember 2016, var et forutgående avslag fra Regional forskningsetisk komite (REK). Dette avslaget ble derfor påklaget til NEM som ga tillatelse etter klagesaksbehandling.

${ }^{35} \mathrm{Vi}$ skiller i det følgende for klarhetens skyld mellom de «sakkyndige» i de aktuelle rettssakene og de «medisinske» forfatterne til denne artikkelen.
} 
Ved gjennomgangen av den medisinske dokumentasjonen møttes de tre medisinske forfatterne $\mathrm{i}$ samme rom, hvor de satt atskilt og vurderte dokumentasjonen for hver enkelt pasient, idet dokumentasjonen for hvert enkelt barn sirkulerte mellom dem. Symptomer, kliniske funn og radiologiske funn ble for hver pasient notert på et fast skjema, og den enkelte forfatter gjorde seg også opp en mening om hva som feilte barnet. Først deretter konfererte forfatterne med hverandre. Ved denne første gjennomgangen manglet vesentlig informasjon for enkelte barn. Ytterligere informasjon måtte derfor innhentes i ettertid før tilstanden kunne sluttvurderes.

Én av medisinerne (JW) har formell kompetanse i vurdering av radiologisk dokumentasjon, men de to andre hadde som nevrokirurger en betydelig praktisk/klinisk erfaring med radiologiske vurderinger av hjerne- og hodeskader hos barn. Vurderingen av den radiologiske dokumentasjonen var ikke forskjellig for de tre, men vurderingen til spesialisten i nevroradiologi ble tillagt spesiell vekt når det gjaldt detaljer, som alder av intrakranielle blodansamlinger og målinger av blødningens (hematomets) størrelse etc.

\section{$30 \mathrm{~m}$ rettens mulighet til å fastslå om filleristing har skjedd eller ikke}

Gjennomgående vil alle rettslige vurderinger i saker om filleristing være helt avhengig av medisinfaglig ekspertise for domsavsigelse. Siden verken politiet, påtalemyndigheten eller domstolene har selvstendig medisinsk kompetanse til å vurdere foreliggende medisinsk dokumentasjon, er det viktig at de sakkyndiges vurderinger er bygget på solid, vitenskapelig holdbar dokumentasjon. Som nevnt innledningsvis er det reist atskillig tvil om funn av triaden eller dens delkomponenter kan tillegges avgjørende vekt som bevis på filleristing. ${ }^{36}$ I vårt materiale har de sakkyndige som regel vært rettsmedisinere. Men også andre spesialister, som for eksempel barnenevrologer, barneleger og øyeleger, innehar en ekspertise som er benyttet i praksis.

Når barn ristes tilstrekkelig kraftig, er det som nevnt lagt til grunn at dette kunne forårsake akutt hjerneskade med subdural blødning og netthinneblødning. ${ }^{37}$ Risting av barn antas å utløse sterke krefter tilsvarende store hodeskader. Hodet er uforholdsmessig tungt på et barn på under seks måneders alder, samtidig som hjernen har konsistens omtrent som gelé og flyter i hjernevæsken inne i skallen. Men som påpekt kan hjerneskader og netthinneblødning også ha andre årsaker enn risting.

Det mangler tilstrekkelig vitenskapelig dokumentasjon på om triadens diagnostiske verdi alltid er riktig. Samtidig er det umulig av etiske grunner å gjennomføre forskning for å kunne sannsynliggjøre eller falsifisere en årsakssammenheng mellom skademåte og skadefølge. Det foreligger i dag uenighet om triadens diagnostiske verdi blant medisinske eksperter både i Norge ${ }^{38}$, Sverige $^{39}$ og i flere anglosaksiske land ${ }^{40}$.

\footnotetext{
${ }^{36}$ SBU s. 12.

${ }^{37}$ Dr. A. N. Guthkelch formulerte i 1971 en hypotese vedrørende årsaker til barnemishandel. Denne hypotesen utviklet seg til en «teori» om SBS som levde sitt eget liv. De siste ti-årene av sitt liv ble Guthkelch en tviler fordi det ikke finnes noen sikker vitenskap bak hans hypotese, og han mente at uriktige domfellelser har skjedd på grunn av uriktige sakkyndigvurderinger. Se A. N. Guthkelch, «Problems of infant retino-dural hemorrhage with minimal external injury», 12 Houst J Health Law Policy 2012 s. 201-208. Artikkelen avsluttes med: «we need new research on the pathology rather than a vain repetition of hypotheses. In obtaining a better understanding of the pathology, such research will assist in the earlier diagnosis and treatment of sick or injured children; it will also serve the cause of justice.»

${ }^{38}$ Fra diskusjonen i Tidsskriftet for legeforeningen, se K. Westers innledende kronikk:

https://tidsskriftet.no/2018/09/kronikk/har-et-filleristet-spedbarn-alltid-vaert-filleristet. 18 forfatteres motinnlegg: https://tidsskriftet.no/2018/12/debatt/legers-rolle-ved-mistanke-om-alvorlig-barnemishandling og Westers tilsvar til dette: https://tidsskriftet.no/2019/01/debatt/grunnleggende-uenighet-om-filleristing

${ }^{39} \mathrm{https}$ ://www.lakartidningen.se/Klinik-och-vetenskap/Kommentar/2018/03/Triaden-racker-inte-for-att-

diagnostisera-skakvald/

${ }^{40}$ Følgende er en konsensusartikkel fra 2019 om SBS/AHT: A. K. Choudhary et al., Pediatric Radiology, August 2018, Volume 48, Issue 8, s. 1048-1065. «Consensus statement on abusive head trauma in infants and young children». https://link.springer.com/article/10.1007\%2Fs00247-018-4149-1. Det tradisjonelle synet på triaden og hele SBS/AHT-diagnosen har møtt betydelig motstand fra ikke minst jurister i USA, som har publisert kritikk
} 


\section{De aktuelle straffesaker om filleristing}

\subsection{Innledning}

I det følgende (punkt 4.2 til 4.18) behandles de 17 sakene der vi har både rettslige og medisinske dokumenter. Først beskrives hva domstolene i straffesaken har lagt til grunn, herunder en beskrivelse for hvilke redegjørelser de sakkyndige har framlagt for retten, i sakkyndigerklæringer og muntlig under rettsforhandlingene. Dette suppleres så av en re-vurdering av de medisinske dokumentene ved de tre medisinske medforfatterne. Deres tilnærming for å kunne foreta denne faglige ettervurderingen framgår av punkt 2.2.

Bare to saker er blitt behandlet av Høyesterett ettersom Høyesterett ikke kan prøve lagmannsrettens bevisvurdering under skyldspørsmålet. De to sakene gjaldt henholdsvis straffenivået ved denne type voldsskader mot spedbarn (punkt 4.18) og et lovtolkingsspørsmål.

Saken om lovtolkning gjaldt en far som ble dømt for legemsbeskadigelse med døden til følge. Tema for Høyesteretts første behandling (HR-2019-509-A) var vurderingen av skyldkravet dolus eventualis ved forsettlig skadepåføring. Også den etterfølgende lagmannsrettsdommen (LB-2018-63160) ble prøvd av Høyesterett (HR-2019-509-A) som behandlet både skyldkravet og spørsmålet om det forelå «særdeles skjerpende omstendigheter». Her foreligger ikke en etterfølgende revurdering av de medisinske vurderingene fordi saken ikke ble omfattet av gitte tillatelser, og den omtales ikke nedenfor.

\subsection{Mor frikjent for filleristing fordi hun ikke var riktig tiltalt}

I en straffesak ble mor domfelt i tingretten (TOSLO-2004-65461) for å ha slått/sparket sin da tre måneder gamle sønn slik at han fikk betydelige hodeskader og en rekke ribbeinsbrudd, og/eller ha filleristet ham, slik at han fikk brudd i skallebeinet, blødning under den harde hjernehinne, kontusjonsskader og blødninger i hjernevevet, blødning under huden på hodet og brudd i åtte ribbein, strl. $1902 \S 229$ andre straffalternativ, jf. strl. $1902 \S 232$. Hun ble frikjent ved lagmannsrettens ankebehandling (LB-2005-49205).

I tingretten uttalte de to sakkyndige:

Det er ikke mulig å forklare de påviste skader på annen måte enn at barnet har vært utsatt for vold direkte mot hodet, enten ved at barnet løftes opp og legges hardt mot underlaget eller svinges rundt på en slik måte at barnet treffer en fast gjenstand. Ribbeinsbruddene forklares best ved at noen har holdt rundt barnets brystkasse og presset sammen, eventuelt etterfulgt av «filleristing» av barnet som har forårsaket blødningene under den harde hjernehinne baktil mellom de to hjernehalvdeler, og over begge hjernehalvdeler baktil. Den noe eldre blødningen i venstre pannelapp kan også vært forårsaket av slik «filleristing».

Tingrettens dom ble fengsel ett år og seks måneder, hvorav 90 dagers ubetinget fengsel.

Ved ankesaken for lagmannsretten ga tiltalte en forklaring som i vesentlig grad avvek fra de forklaringene hun tidligere hadde gitt til politiet og i tingretten. Mor kom til Norge fra Pakistan i 1990. Hun forklarte at ektemannen hadde presset henne til å forklare seg uriktig ved å true med å gå fra henne. En skilsmisse ville - særlig fordi hun var skilt en gang tidligere - $\mathrm{i}$ hennes kultur være svært nedverdigende for en kvinne, og hun hadde derfor gått med på ektemannens krav.

\footnotetext{
sammen med leger. Se f.eks. R. Papetti, P. Kaneb og L. Herf, «Outside the Echo Chamber, A Response to the 'Consensus Statement on Abusive Head Trauma in Infants and Young Children'», 59 Santa Clara L. Rev. 299, 2019, K. A. Findley, 12 Houston Journal of Health Law \& Policy, 209 ISSN 1534-7907 og D. A. Moran, «Shaken Baby Syndrome, Abusive Head Trauma, and Actual Innocence: Getting it Right.», K. A. Findley, P. D. Barnes og W. Squire, co-authors. House. J. Health L. \& Pol'y 12, no. 2, 2012, s. 209-312. Se bloggen sci-cri på https://www.sci-cri.com/blog.
} 
Opprinnelig ble straffesak mot barnets far henlagt. Etter frifinnelsen av barnets mor, ble det vurdert om saken mot barnets far skulle gjenåpnes. Fordi det ikke var mulig å få nye forklaringer, ble en begjæring om gjenåpning av straffesaken avvist ved påtegning av riksadvokaten i $2007 .^{41}$

Den fellende dommen i tingretten bygde dels på morens falske tilståelse og dels på de sakkyndiges vurdering av hvordan barnets skader hadde oppstått.

Etter en ny analyse av det foreliggende medisinske materialet har de tre medisinerne blant artikkelforfatterne konkludert med at skadene var forenlig med påførte traumer, slik at dommen i tingretten synes basert på riktig faktum. Frikjennelsen i lagmannsretten bygde derimot på annet grunnlag.

\subsection{Far dømt for uaktsom skadeforvoldelse av to måneder gammel sønn}

I en straffesak (TAUAG-2005-36491) ble far dømt for å ha ristet eller klemt sin to måneder gamle sønn slik at det oppsto brudd i 17 ribbein. Ved en annen anledning hadde han vridd eller slått barnets høyre bein slik at det oppsto lårbeinsbrudd. Straffen ble satt til fengsel i to år og seks måneder. I tillegg ble han dømt til å betale sønnen en oppreisningserstatning på 45000 kroner.

Under hovedforhandlingen redegjorde en av de to sakkyndige nærmere for shaken baby syndrome. I tillegg til de to sakkyndige hadde en tredje sakkyndig gjennomgått røntgenbildene i saken. Den sakkyndige konkluderte med at den klassiske triaden ved SBS syntes å foreligge, kombinert med ribbeinsbrudd.

Ved ankebehandlingen (05-097573AST-ALAG) svarte juryen nei på spørsmålene om strl. 1902 $\S 229$ tredje straffalternativ, jf. § 232, nei på strl. 1902 § 219 andre straffalternativ og nei på strl. 1902 $\S 228$ første ledd, jf. § 228 andre ledd andre straffalternativ. Etter enda en subsumsjonsendring svarte lagretten ja på strl. $1902 \S 238$ for uaktsomt å ha voldt betydelig skade på en annens legeme. Straffen ble i henhold til dette endret til fengsel i fem måneder. Hvilken vekt de ulike skadene har hatt på straffutmålingen, er umulig å svare på.

Etter en ny analyse av det foreliggende medisinske materialet har de tre medisinerne blant artikkelforfatterne konkludert med at de kliniske og radiologiske tegnene i denne saken er forenlig med ekstern hydrocefalus, som kan ha forårsaket eller predisponert for subdurale blødninger.

\subsection{Far dømt for grovt uaktsom legemsfornærmelse med betydelig følgeskade overfor seks måneder gammel sønn}

En far ble i tingretten dømt for grovt uaktsomt å ha legemsfornærmet sin seks måneder gamle sønn med betydelig skade til følge (TKISA-2006-69702). Retten la til grunn at faren hadde ristet sønnen i frustrasjon for å stoppe gråt. Sønnen ble som følge av dette påført en betydelig hjerneskade. Ingen andre skader er nevnt. Straffen ble fastsatt til ett års fengsel hvorav seks måneder ble gjort betinget. Han ble i tillegg dømt til å betale sønnen 900000 kroner i erstatning for tap i framtidig erverv og menerstatning, og 100000 kroner i oppreisningserstatning.

Dommen ble påanket (LA-2006-165987), og saken ble for lagmannsretten opplyst gjennom en omfattende medisinsk bevisførsel. Fem personer ble gitt status som sakkyndige vitner, hvorav en møtte under straffesaken. Av dommen framgår:

Det bærende grunnlaget for den fellende dom er derfor de slutninger som ved sakkyndigbevis kan trekkes av observerte skader, spesielt kombinasjonen av blødning under den harde hjernehinne, netthinneblødning og hjerneskade, sammenholdt med den omstendighet at siktede var alene om omsorgen for barnet i den tiden skaden må ha inntruffet uten at noen alternativ forklaring er påvist.

Lagmannsretten dømte far for overtredelse av strl. $1902 \S 228$ andre ledd andre straffalternativ om legemsfornærmelse med betydelig skade til følge. Lagretten svarte nei på spørsmål om forsett med hensyn til skadefølgen. Straffen ble deretter fastsatt til fengsel i ett år og tre måneder, hvorav seks måneder ble gjort betinget.

\footnotetext{
${ }^{41}$ RA 7380964 1070/06-63/IFO002.
} 
Sønnen var blitt påført en meget omfattende hjerneskade, både i storhjernen og lillehjernen. I tillegg ble det ved undersøkelse ved øyelege konstatert omfattende blødninger i netthinnen på begge øyne. Disse skader ble ansett som karakteristiske for øyeskader man ser ved SBS.

Retten fant det bevist utover enhver rimelig tvil at de skader som gutten var blitt påført ikke skyltes uhell eller sykdom, herunder fallulykker, beinskjørhet eller andre skjelettsykdommer, men var et resultat av mishandling gjennom ytre vold. Av dommen framgår at det bærende grunnlaget for den fellende dommen var filleristingskader. Under tvil ble legemsfornærmelsen dog ikke ansett begått under særdeles skjerpende omstendigheter, jf. strl. 1902 §232. Retten la til grunn at skaden var skjedd ved at tiltalte i frustrasjon hadde ristet barnet kraftig. Fornærmede ble tilkjent oppreisningserstatning med 75000 kroner. Full erstatning etter skadeserstatningsloven § 3-2a utgjorde vel 2,5 millioner kroner, et beløp som ble lempet til en million kroner i medhold av skadeserstatningsloven § 5-2.

Etter en ny analyse av det foreliggende medisinske materialet har de tre medisinerne blant artikkelforfatterne konkludert med at dette barnet, som var født svært prematurt, har radiologiske funn forenlig med en utbredt hjerneskade, slik man kan se etter oksygenmangel eller manglende blodtilførsel til hjernen eller deler av denne. Man kan ikke utelukke at tilstanden er forårsaket av en spontant oppstått medisinsk tilstand.

\subsection{Far dømt for alvorlig legemsskade med døden til følge overfor fire uker gammel datter}

I tingretten (TDRAM-2006-173511) ble en far dømt til fengsel i fem år for overtredelse av strl. 1902 $\S 229$ tredje straffalternativ, jf. $\S 232$. Retten var ikke i tvil om at far hadde ristet sin fire uker gamle datter så kraftig at hun ble påført SBS. I tillegg var datteren påført et kraftig traume som følge av stump vold mot hodet, og hun døde som følge av økt trykk i hjernen. Det var dissens angående straffutmålingen.

Jenta ble obdusert og det ble avlevert tre sakkyndige rapporter i saken. Av den ene rapporten framgår at «B hadde flere brudd som også er karakteristiske ved shaken-impact syndrome».

Den sakkyndige beskrev under ankeforhandlingen en fraktur eller et brudd på ca. fire $\mathrm{cm}$ bak tinningen på venstre side av kraniet. I tillegg til de skader som ble funnet under operasjonen, ble det også konstatert strekkskader på nervetråder i hjernen og blødninger i netthinnen på det venstre øyet.

I lagmannsretten (LB-2007-81085) ble straffutmålingen på fem års fengsel opprettholdt. Tiltalte ble også der dømt for overtredelse av strl. $1902 \S 229$ tredje straffalternativ, jf. § 232.

Det framgår av dommen at med iretteføring innen rimelig tid ville straffen ha vært satt til fengsel $\mathrm{i}$ seks år, men som følge av lang saksbehandlingstid ble den satt til fengsel i fem år.

Ifølge innkomstjournalen i sykehus fortalte foreldrene at spedbarnets 16 måneder gamle storesøster hadde falt over henne da hun lå på badegulvet for å bli stelt. Nærmere omstendigheter omkring dette traumet er ikke kjent. Dagen etter denne hendelsen ble hun ifølge innkomstjournalen «brått svært irritabel, skrek utrøstelig og har ikke villet spise», hvoretter hun gradvis ble dårligere. Ved innleggelsen i sykehus samme dag «skrek hun hele tiden», men var ved bevissthet. Morgenen etter innleggelsen i sykehus hadde hun utviklet «venstresidig blikkparese» (kunne ikke se mot venstre) og en stor, lysstiv pupille på det venstre øyet, tydende på kraftig forhøyet intrakranielt trykk, samtidig som hun falt i bevissthet. CT-unders $ø$ kelse viste da en hoven hjerne med flere blodansamlinger i hjernevevet. I tillegg viste CT-undersøkelsen et skallebrudd i form av en sprekk i venstre issebein. Hun ble operert med uttømming av en blodansamling i hjernens venstre pannelapp. Postoperativ MRunders $\varnothing$ kelse viste en omfattende hjerneskade i begge storhjernehalvdeler, beskrevet slik i journalnotat av nevrokirurg: «Bildet ligner mest på en asfyksiskade med global ischemi» (=skade på grunn av oksygenmangel til store deler av hjernen).

Som alltid ved lagrettens kjennelser er det uvisst hvilken beviskraft de sakkyndiges vurderinger har hatt.

Etter en ny analyse av det foreliggende medisinske materialet har de tre medisinerne blant artikkelforfatterne konkludert med at dette barnet har radiologiske funn forenlig med en utbredt hjerneskade, slik man ser etter oksygenmangel eller manglende blodtilførsel til storhjernen. Man kan ikke utelukke at tilstanden er forårsaket av en spontant oppstått medisinsk tilstand. Det finnes også blødninger i hjernevevet og under den harde hjernehinnen (subduralt hematom). Det finnes samtidig 
tegn på traume i form av skallebeinsbrudd. Hvorvidt sprekken i skallen skyldes en fødselsskade, storesøsterens fall eller en påført skade, kan ikke avgjøres på grunnlag av foreliggende dokumentasjon.

\subsection{Mors samboer først frifunnet, deretter straffed $\varnothing \mathrm{mt}$ for filleristing av tre måneder gammel gutt}

I tingretten (TOSLO-2007-140898) ble mors samboer frifunnet for overtredelse av strl. $1902 \S 228$ andre ledd, jf. § 232, for filleristing av en tre måneder gammel jente. Den rettsoppnevnte sakkyndige forklarte i retten at barnet hadde to av tre funn som utgjør shaken baby syndrome, nemlig blødning under den harde hjernehinnen og netthinneblødninger. Barnet hadde ikke hjerneskade som er det tredje kriteriet for en SBS-konstatering.

Hyppige funn som bruddskader og blåmerker i huden manglet også. Den sakkyndige forklarte at det likevel var overveiende sannsynlig at barnets skader skyldes akselerasjon/deselerasjonskader på grunn av kraftig risting.

Tingretten fant at det forelå en slik grad av tvil rundt hendelsesforløp og årsakssammenheng vedrørende barnets skader at det ikke forelå tilstrekkelig grunnlag for domfellelse. I denne saken ble et manglende kriterium i triaden vurdert som et frifinnende moment.

Påtalemyndigheten anket saken, og i lagmannsretten (LB-2008-73002) ble mors samboer domfelt. Men forsettet ble ikke ansett å omfatte skadefølgen. Barnet hadde blødninger under den harde hjernehinne og netthinneblødninger. I sin uttalelse konkluderte den sakkyndige med at barnets skader indikerte «risteskade», selv om det ikke forelå tegn på varig hjerneskade etter fire år.

Det ble kommentert at et enkelt tilfelle av risting ikke vil medføre blødninger under den harde hjernehinne med mindre det er utført med meget stor kraft, betydelig større enn beskrevet i tiltaltes forklaring. Dette gjelder i enda større grad netthinneblødninger. Derimot er begge skader typiske for SBS. Dette er skader som kan oppstå hos spedbarn ved gjentatt akselerasjon/deselerasjon av hodet.

Tiltalte erkjente å ha ristet jenta kraftig ved enkelte anledninger. Hans forklaring i lagmannsretten om at han i politiavhøret hadde ment vugging, var ikke troverdig. Etterforskeren som gjennomførte avhøret, forklarte at man den gang la stor vekt på å klargjøre hva tiltalte mente med risting. Tiltalte hadde blitt spurt hva han mente, og hadde da vist dette som å holde barnet ut fra kroppen, rundt brystet, og riste fram og tilbake. Det tiltalte viste, var det som etterforskeren oppfattet som risting, og ifølge etterforskeren ikke oppfattes som vugging. Tiltalte ble bedt av etterforskeren om å angi det engelske ordet for hva han hadde gjort, og brukte da ordet «shaking».

Lagmannsrettens flertall fant det på bakgrunn av den sakkyndiges forklaring utvilsomt at jenta ble ristet kraftig og at dette forårsaket skadene.

Lagmannsrettens mindretall mente det knyttet seg begrunnet tvil til saken. Mindretallet mente det ikke kunne utelukkes at det hele startet med et fall som førte til bevissthetstap, og at jentas mor da hun deretter forståelig nok prøvde å få liv i barnet, bidro til skaden ved å ta for hardt i. Mindretallet mente at denne tvilen måtte føre til frifinnelse.

Straffen ble fastsatt til fengsel i ett år og seks måneder, hvorav seks måneder ubetinget. Det ble tatt hensyn til at saken var blitt gammel hos politiet. Barnet ble tilkjent oppreisningserstatning på 30000 kroner.

Etter en ny analyse av det foreliggende medisinske materialet har de tre medisinerne blant artikkelforfatterne konkludert med at barnet hadde en blanding av akutt og kronisk subdural blodansamling - den største, kroniske delen var av varierende alder, noe som vanskelig kan forklares med at den oppsto som følge av én enkelt episode.

Det kan altså reises spørsmål ved om flertallets konklusjon i lagmannsretten er basert på rett faktum, dvs. at det er årsakssammenheng mellom erkjent risting og skadene påvist hos barnet.

\subsection{Far dømt for filleristing av datter på fem uker}

Far dømt i tingretten (TRANA-2008-107124) til fengsel i fire år, hvorav seks måneder ble gjort betinget, for overtredelse av strl. $1902 \S 229$ tredje straffalternativ, jf. $§ 232$. Fornærmet var tiltaltes datter på fem uker, og skaden var forårsaket av filleristing. Tiltalte erkjente selve handlingen, men ikke forsett. I tillegg ble han dømt til å betale oppreisningserstatning på 75000 kroner til datteren. Dommen var fellesdom med resttid og betinget del av tidligere dom for voldtekt.

To sakkyndige ble oppnevnt hvorav én møtte i tingretten og uttalte at: 
[d]et er rimelig å anta at triaden: blødning under den harde hjernehinnen, diffus aksonal skade i hjernen og blødninger i øyebunnen, har oppstått i samme hendelse ved kraftig filleristing.

Retten la etter dette til grunn at de skader barnet ble påført, skyldes risting fra tiltaltes side.

Ved ankebehandlingen i lagmannsretten (LH-2008-160684) ble det lagt til grunn at datteren ble påført betydelig skade som blødning under den harde hjernehinnen, oppsvulming av hjernen med betydelig tap av hjernevev og utbredte blødninger i øyebunnen på begge sider, ved at tiltalte i minst fire til seks sekunder ristet henne kraftig og hurtig slik at hodet hennes beveget seg fram og tilbake uten noen form for støtte. Straffen ble i lagmannsretten den samme som i tingretten, fengsel i fire år.

Etter en ny analyse av det foreliggende medisinske materialet har de tre medisinerne blant artikkelforfatterne konkludert med at dette barnet har radiologiske funn forenlig med en utbredt hjerneskade, slik man kan se etter oksygenmangel eller manglende blodtilførsel til hjernen eller deler av denne. Man kan ikke utelukke at tilstanden er forårsaket av en spontant oppstått medisinsk tilstand. Denne alternative forklaringen til skadene åpner derfor for tvil om det foreligger straffansvar.

Det kan altså reises spørsmål ved om konstateringen av filleristing som årsak til skadene er riktig, dvs. at det foreligger årsakssammenheng mellom erkjent risting og skadene påvist hos barnet.

\subsection{Far dømt for filleristing av sønn på elleve uker}

En 25 år gammel far ble i tingretten (TVTRA-2009-202645) dømt til fengsel i 13 måneder, hvorav seks måneder betinget, for å ha filleristet sin elleve uker gamle sønn slik at han ble påført

hjerneblødning og netthinneblødning. Far ble dømt for legemsfornærmelse, strl. $1902 \S 228$ andre ledd første straffalternativ. Det var ikke påvist varig skade, men dette kunne ikke utelukkes før gutten ville bli åtte til ti år. Gutten ble tilkjent oppreisningserstatning med 40000 kroner.

I tingretten var det to sakkyndige. De konstaterte blødninger under den harde hjernehinnen og blødninger i netthinnen. Begge skader er ifølge de sakkyndige typiske ved filleristing.

Ved ankebehandling i lagmannsretten (LH-2010-96312) fant de to rettsoppnevnte sakkyndige ingen annen rimelig forklaring enn at skadene var påført ved filleristing. Symptomene som barnet viste ved stell hjemme og hos legen like etter at tiltalte hadde vært inne hos ham, støttet ifølge de sakkyndige opp under at han like før hadde blitt filleristet.

Lagmannsretten delte seg i et flertall og et mindretall når det gjaldt skyldspørsmålet.

Flertallet fant det bevist ut over rimelig tvil at tiltalte hadde ristet sin sønn kraftig slik at han fikk blødning under den harde hjernehinnen og netthinneblødninger på begge øyne.

Mindretallet fant det ikke bevist ut over rimelig tvil at tiltalte hadde forholdt seg som beskrevet $\mathrm{i}$ tiltalebeslutningen. Mindretallet er enig med flertallet i at sønnen er påført skader som følge av filleristing, men kan ikke helt se bort fra at skadene kan ha blitt påført tidligere. Det er alt $i$ alt en rimelig mulighet for at andre enn tiltalte kan ha påført sønnen skadene som er påvist.

I tråd med flertallets syn ble tiltalte domfelt. Lagmannsretten trakk fra en måned av tingrettens dom og idømte fengsel i ett år hvorav seks måneder betinget.

Etter en ny analyse av det foreliggende medisinske materialet har de tre medisinerne blant artikkelforfatterne konkludert med at det ses kliniske og radiologiske tegn forenlig med ekstern hydrocefalus, som kan ha forårsaket eller predisponert for subdurale blødninger. Denne alternative forklaringen til skadene åpner derfor for tvil om det foreligger straffansvar.

\subsection{Foreldrepar $\mathrm{d} \varnothing \mathrm{mt}$ for filleristing av et barn i tingretten, men frifunnet av lagmannsretten}

Et foreldrepar ble i tingretten (TOSLO-2009-148479) tiltalt for mishandling av sine to barn, en jente på 15 måneder og en gutt på to år. Det er bare datterens skader som er koblet til filleristing. De sakkyndige uttalte i tingretten om hennes skader:

Kombinasjonen av blødning under den harde hjernehinnen, betydelig hevelse av hjernen og blødninger i øyebunnen på begge sider sannsynliggjør at det her dreier seg om et tilfelle av kraftig risting av barnet ved at en voksen person har holdt omkring brystkassen slik at hodet har blitt utsatt for kraftige akselerasjons- og deselerasjonsbevegelser (såkalt shaken-baby-syndrom).

Skallebruddene tilsier at barnet i tillegg har blitt utsatt for minst to tilfeller av kraftig stump vold 
som slag mot eller med venstre side av hodet mot en stump gjenstand. Barnet kan ikke selv ha påført seg noen av disse skadene.

Sønnens skader var av annen art.

I klinisk undersøkelse noterte de sakkyndige at det ved MR av datteren var påvist store skader i hele venstre hjernehalvdel og fremre del av høyre hjernehalvdel. Hevelsen og misfargingen på høyre side av pannen antas å være et resultat av stump vold som ved slag med eller støt/fall mot stump/flat gjenstand/underlag. Skaden ble antatt å være noen få dager gammel. Det ble også funnet et skorpekledd skrap i samme området, samt to små sårskorper på høyre albue. Det ble endelig påvist blødninger i øyebunnen som så ut som forandringer beskrevet i forbindelse med kraftig risting.

Det foreligger også mistanke om engelsk syke (rakitt) på grunn av D-vitamin mangel. De sakkyndiges vurderinger gjorde det dog klart at barnets skader ikke kunne forklares ved denne formen for beinskjørhet.

De sakkyndige konkluderer etter den kliniske undersøkelsen i tråd med sitatet ovenfor.

Foreldrene ble dømt for grov vold og mishandling av begge barna. Retten fant det bevist at far ved passivitet hadde medvirket til voldsut øvelsen. Han ble idømt fengsel i tre år og seks måneder. Også for mor fant retten det bevist at hun ved passivitet hadde medvirket til voldsutøvelsen. Hennes dom ble fengsel i to år seks måneder, hvorav ett år betinget.

Begge anket til lagmannsretten (LB-2010-30302) der de begge ble frifunnet. Lagretten besvarte de to hovedspørsmålene gieldende skyldspørsmålet med nei. Foreldrene ble frifunnet for kravet om straff, men dømt, som i tingretten, til solidarisk å betale oppreisningserstatning med 300000 kroner til datteren og 100000 kroner til sønnen. Retten kom fram til at foreldrene med klar sannsynlighetsovervekt hadde mishandlet sine barn:

Etter en samlet vurdering av bevisene i saken finner lagmannsretten klar sannsynlighetsovervekt for at A og B har mishandlet sine barn eller medvirket til dette ved samtykke eller tilskyndelse til handlingene, over lang tid fram til 26. januar 2008. Lagmannsretten finner videre klar sannsynlighetsovervekt for at foreldrene påførte eller medvirket til å påføre C store hodeskader, og at de påførte eller medvirket til å påføre D skader ved gjentatt vold, herunder vridningsbrudd i armen.

Ved bevisvurderingen legger retten vekt på at flere av de skader som er påvist på barna ikke er forenlige med hendelige uhell, men tvert om vitner om at de er påført ved kraftig vold.

Ved gjennomgang av journalen framkommer det at datteren hadde en sikkert etablert rakitt-diagnose («engelsk syke»).

Etter en ny analyse av det foreliggende medisinske materialet har de tre medisinerne blant artikkelforfatterne konkludert med at det foreligger en sikkert traumatisk betinget hode- og hjerneskade. Det er kjent at fall fra en viss høyde (barnets egen høyde) kan forårsake alvorlig hodeskade med kraniebrudd, ${ }^{42}$ det lave kalkinnholdet i hennes skjelett pga. rakitt $\varnothing$ ker risikoen for brudd.

\subsection{Far $\mathrm{d} \varnothing \mathrm{mt}$ for ha ristet sin tre måneder gamle datter med hjerneskade til følge}

Far ble tiltalt og dømt i tingretten (TBERG-2012-44519) for å ha ristet sin tre måneder gamle datter slik at hun ble påført hodeskader, jf. strl. $1902 \S 229$ andre straffalternativ, jf. § 232, til fengsel i ett år og to måneder. Han ble dømt til å betale datteren en oppreisningserstatning på 50000 kroner.

Da det ikke var rapporter om at datteren hadde vært utsatt for noen ulykke, mistenkte sykehuset at hun hadde blitt utsatt for kraftig risting og var blitt påført shaken baby syndrome.

Rettens flertall la til grunn som bevist at barnet var blitt påført skader gjennom hardhendt risting. Ved bevisvurderingen la retten avgjørende vekt på de medisinskfaglige forklaringene av skadebildet

${ }^{42}$ Case ME. Accidental traumatic head injury in infants and young children. Brain Pathol. 2008, vol. 18, s. 583589. 
og at andre årsaksmekanismer kunne utelukkes. De to rettsoppnevnte medisinsk sakkyndige fant at det hos barnet var påvist utbredte blødninger under den harde hjernehinnen og under hjernens spindelvevshinne, kontusjonsblødninger (knusningsblødninger) i hjernebarken samt oksygenmangelskade i hjernen. I tillegg var det påvist øyenbunnblødninger i begge øyne, samt et mindre blåmerke på høyre kinn. Både blødningsmønsteret i hjernen og i øyenbunnene underbygde risting som skademekanisme. CT- og MR-unders $ø$ kelser underbygde de sakkyndiges forklaringer, noe som også ble støttet av medisinskfaglig vitneførsel fra tre andre spesialister, herunder i radiologi og øyesykdommer.

I tillegg til ovennevnte sakkyndige viste retten særlig til forklaringen fra to barneleger som var blant barnets behandlende leger på barneklinikken. I denne saken var det solid sakkyndig kompetanse fra flere spesialiteter og enighet om konklusjonen.

Mindretallet fant det ikke bevist ut over enhver rimelig tvil at tiltalte har forholdt seg som beskrevet i tiltalebeslutningen. Mindretallet så ikke helt bort fra at skaden kunne ha oppstått på et tidligere tidspunkt enn da tiltalte var alene sammen med fornærmede. Det er da en rimelig mulighet for at andre enn tiltalte kan ha ristet barnet. Når det gjelder blåmerket utelukket ikke mindretallet at dette kunne ha kommet ved et uhell som tiltalte ikke var oppmerksom på. Hensett til tvilsprinsippet mente mindretallet dermed at tiltalte måtte bli å frifinne.

I samsvar med flertallets syn ble tiltalte domfelt. Dommen ble ikke anket.

Etter en ny analyse av det foreliggende medisinske materialet har de tre medisinerne blant artikkelforfatterne konkludert med at dette barnet har radiologiske funn forenlig med en utbredt hjerneskade, slik man kan se etter oksygenmangel eller manglende blodtilførsel til hjernen eller deler av denne. Man kan ikke utelukke at tilstanden er forårsaket av en spontant oppstått medisinsk tilstand.

\subsection{Uklart hvem som hadde filleristet en månedsgammel gutt}

En mor og hennes foreldre ble frikjent av tingretten (TRING-2012-196680) for tiltale etter strl. 1902 $\S 242$ første og andre ledd. Fornærmet var en én måned gammel gutt. Det ble sannsynliggjort av sakkyndige at barnet hadde blitt filleristet, men det var uklart hvem av tre mulige kandidater, moren og hennes foreldre, som hadde påført skadene. De var alle tre tiltalt for å ha unnlatt å skaffe barnet legehjelp. Men retten fant det ikke tilstrekkelig bevist at noen av dem med forsett unnlot å skaffe legehjelp til barnet.

Den medisinsk sakkyndige påviste ytre skader som underhudsblødning på venstre kinn, støt- og skrapskader på høyre side av rygg og seteregion samt utad på venstre lår. Røntgenologisk unders $\emptyset$ kelse viste $\varnothing \mathrm{kt}$ trykk i hodeskallen ved at sømmene mellom skallebeina var presset fra hverandre. Det var dessuten blodansamling over begge hjernehalvdeler, mellom hjernehalvdelene og i bakre skallegrop. Blodansamlingene viste ulike nedbrytningsfaser og hadde trolig forskjellig alder. Det var brudd av ribbein $1 \mathrm{og} 11$ på høyre side baktil inn mot virvelsøylen.

Samtidig var det noen beskjedne blødninger i netthinnene i begge øyne, som ikke kunne utelukkes å stamme fra en fødselsskade.

Om mulige årsaker til skadene uttalt den sakkyndige:

Skadene er stump vold-skader som har framkommet ved slag med eller fall mot stump gjenstand. Kraftig klem/trykk med hender kan ikke utelukkes. De påviste ribbebruddene ved røntgen CT av brystet er forenlig med kraftig trykk sideveis fra begge sider mot brystkassen. Det kan også tenkes at barnet er holdt med hendene rundt brystkassen og ristet.

Kraftig risting slik at hodet utsettes for betydelig akselerasjon og deselerasjonskrefter kan [føre] til strekk og drag på brosamleåren som forløper mellom skalletaket og hjernen og dermed til at det oppstår bristninger i brosamleårene mellom skalletaket og hjernen med den følge at det blør ut i rommet under den harde hjernehinnen. Slik akselerasjon og deselerasjonsskade kan oppstå i kombinasjon med bruddskader eller bare som følge av risting.

Den sakkyndige påpekte at ikke alle tre kriterier for såkalt filleristningssyndrom var til stede i saken. Blødningene under den harde hjernehinnen var forenlig med filleristing. Imidlertid var netthinneblødningene så beskjedne at de ikke nødvendigvis skyldtes filleristing, men kunne stamme fra fødselen. Det ble heller ikke påvist skader i selve hjernevevet. 
Bevisbildet var ifølge tingretten ikke helt entydig med hensyn til årsakene til blødningene i hodet. I og med at de påviste netthinneblødningene kunne stamme fra fødselen, kunne det bare med sikkerhet legges til grunn at bare ett av tre kriterier for SBS (blødning under den harde hjernehinnen) var til stede. Alle tre ble frikjent.

Ved ankebehandlingen (LB-2013-91572) ble både moren og hennes foreldre dømt etter strl. 1902 $\S 242$ først og andre ledd.

Den sakkyndige, samme som i tingretten, beskrev typiske konsekvenser av filleristing. Dessuten ble det nevnt at det ofte oppstår brudd av ribbein og/eller arm- eller beinbrudd ved filleristing. Symptomer er sløvhet, irritabilitet, redusert bevissthet, epilepsi, rykninger, slappe muskler, oppkast, forandret åndedrett og krampeanfall.

Disse symptomene måtte etter den sakkyndiges vurdering veies opp mot alternative årsaksforklaringer som alvorlige infeksjoner, leukemi, beinskjørhet, blodlevringsforstyrrelser, stoffskiftesykdommer, blødning under senehinnen og netthinneblødning ved hard fødsel. Det vesentligste av dette kunne, etter den sakkyndiges vurdering, utelukkes etter de unders $\varnothing$ kelser som ble gjort av barnet på sykehuset. Den sakkyndige svarte bekreftende på at skadene på barnet mest sannsynlig var påført. Et barn på fire uker vil ikke kunne bevege seg slik at det kan falle og få stump vold-skader slik barnet hadde. Den sakkyndige anså det også helt usannsynlig at blødningene under den harde hjernehinnen skulle være betinget av fødselsskader.

Lagmannsrettens konklusjon ble at symptomene var sammenfallende med dem den sakkyndige hadde beskrevet som konsekvenser av filleristing. Lagmannsretten fant det etter dette utvilsomt at barnet ble påført skadene $\mathrm{i}$ hode og ribbein ved at det hadde blitt filleristet.

Når lagmannsretten la til grunn at barnet hadde blitt filleristet, var det hevet over tvil at det var én av de tre tiltalte som hadde gjort dette ettersom det var opplyst at ingen andre hadde vært alene med barnet. Lagmannsretten hadde imidlertid ikke tilstrekkelige holdepunkter for å konstatere hvem av de tre som har filleristet gutten og derved påført de aktuelle skadene i hodet og ribbeina. Det var heller ikke tilstrekkelige holdepunkter for å fastslå om noen av de to øvrige hadde hatt kjennskap til filleristingen.

Men alle tre hadde med forsett overtrådt strl. 1902 § 242 andre ledd, jf. første ledd, ved å unnlate straks å sørge for legehjelp til barnet når det ble alvorlig syk og hjelpeløs. Straffen for moren ble satt til fengsel i åtte måneder hvorav 120 dager ble gjort betinget. For hver av barnets besteforeldre ble straffen satt til fengsel i fem måneder hvorav 60 dager ble gjort betinget. Oppreisningserstatning til barnet ble satt til 40000 kroner.

Etter en ny analyse av det foreliggende medisinske materialet har de tre medisinerne blant artikkelforfatterne konkludert med at det ses kliniske og radiologiske tegn forenlig med ekstern hydrocefalus, som kan ha forårsaket eller predisponert for subdurale blødninger.

Ut fra deres vurdering framstår derfor dommen som uriktig ved at den fastslo at barnet utvilsomt var filleristet, og dette synes derved ikke å være basert på rett medisinsk faktum.

I straffedommen tar retten imidlertid ikke stilling til hvordan skadene oppsto eller hvem som var ansvarlig for dem. Alle tre ble domfelt for at legehjelp ikke ble tilkalt når barnet ble alvorlig syk, jf. strl. $1902 \S 242$.

\subsection{Mor dømt for å ha ristet sin 17 dager gamle s $\emptyset \mathrm{nn}$}

I tingretten (TSGUD-2013-37016) ble mor idømt fengsel i ett år og seks måneder for overtredelse av strl. $1902 \S 228$ første jf. andre ledd andre straffalternativ, jf. $\S 232$, for å ha ristet sin 17 dager gamle sønn. Sønnen ble påført blødninger under den harde hjernehinnen, netthinneblødninger i begge øyne og hevelser.

De sakkyndige påviste en stor, omfattende og alvorlig skade i hjernebarken og av hjernevevet, og subduralblødning på begge sider av midtlinjen. I området rundt falx cerebri (midtlinjen mellom hjernehalvdelene) ble det også sett blodprodukter. Det ble videre påvist netthinneblødninger (retinablødninger) i begge øyne.

Den ene av de to sakkyndige konkluderte med at det var

overveiende sannsynlig at skaden har oppstått ved et påført hodetraume som f.eks. risting slik at subduralblødning, Øyebunnsblødninger og avrivinger i hjernevevet har oppstått samtidig. Deretter utvikler det seg hjerneødem (hevelser av hjernevevet). Hjerneødemet $\varnothing$ ker hjernens volum og det 
utvikles blodsirkulasjonsproblemer. Dette fører til hjernecelledød (asfyksi - oksygenmangel), kramper, og redusert pustefunksjon med apneer (pustepauser og behov for respirator).

Videre uttalte den andre sakkyndige:

Dersom en klassifiserer Dr. Mirs funn 150812 etter Vinchon et al (J. Neurosurgery) eller Binenbaum et al (J AAPOS) vil pasienten falle inn under moderat til alvorligste kategori netthinneblødninger hvor det er overveiende sannsynlig at skaden skyldes filleristing. Mangelen på strukturelle skader og netthinneblødningens raske oppklaring sentralt kan tyde på at det ikke er brukt svært mye krefter ved en eventuell filleristing. Det er usannsynlig at et så lite fall som beskrevet i a) hake mot gulv eller b) fra mor bryst/mage liggende i en stol hvor hun fikk tak i barnet før det traff gulvet, ville gitt så alvorlige funn som beskrevet av Dr. Mir.

Selv ved alvorlige høyhastighetsskader ser en sjelden annet enn overflatiske småblødninger eller ingen blødning i netthinnene.

I tingretten uttalte den sakkyndige at en svensk forsker, som regnes som en av de mest fremragende fagpersoner på fagområdet risteskader og netthinneblødninger, har uttalt at ved denne typen funn (blødninger i alle netthinnens lag i alle kvadranter på begge øyne) «kan en ikke med $100 \%$ sikkerhet si at det skyldes filleristing, men en kan med $100 \%$ sikkerhet si at det ikke skyldes noe annet». (sic!)

Begge de sakkyndige avviste at skadene kunne være selvpåført av barnet.

Foruten begge de rettsoppnevnte sakkyndige, var to sakkyndige vitner - barnelege og nevroradiolog - «entydige og tvilløse i sin konklusjon med hensyn til at dette måtte være påført risteskade». ${ }^{43}$

Foreligger kombinasjonen hjernevevsskade, subduralblødninger og netthinneblødninger, og det ikke er andre forhold som kan forklare tilstandene, står en overfor påført risteskade.

Lagmannsretten (LE-2013-112647) forkastet tiltaltes anke over straffutmålingen, og straffen ble stående.

Etter en ny analyse av det foreliggende medisinske materialet har de tre medisinerne blant artikkelforfatterne konkludert med at dette barnet har radiologiske funn forenlig med en utbredt hjerneskade, slik man kan se etter oksygenmangel eller manglende blodtilførsel til hjernen eller deler av denne. Man kan ikke utelukke at tilstanden er forårsaket av en spontant oppstått medisinsk tilstand.

\subsection{Far dømt for legemsfornærmelse under særdeles skjerpende omstendigheter overfor fire måneder gammel sønn}

En far ble i tingretten (TDRAM-2014-178324) dømt for legemsfornærmelse med skade til følge under særdeles skjerpende omstendigheter overfor sin fire måneder gamle sønn, jf. strl. $1902 \S 228$ andre ledd første straffalternativ, jf. $§ 232$. Barnet hadde fått hjernehinneblødning som følge av voldsut $\varnothing v e l s e n$, men ikke varige skader.

I tingretten var det to rettsoppnevnte sakkyndige. De uttalte tvil vedrørende årsaken til skadene:

En mulighet for at barnet er blitt utsatt for kraftig filleristing, men at det ikke kan utelukkes at skaden kan ha skjedd fra et fall.

Den ene supplerte med følgende vurdering:

Når en ikke finner skallebrudd men likevel blødninger under hjernehinnene må en mistenke at risting kan være årsaken. Det skal ganske kraftig rusken fram og tilbake for å utløse sådan blødning.

Videre:

\footnotetext{
${ }^{43}$ Fra tingrettsavgjørelsen, TSGUD-2013-37016.
} 
Det kan dreie seg om et fall fra høyde (minst 1 meters høyde), kraftig filleristing eller annen skademekanisme med tilsvarende stor kraftpåvirkning, for eksempel slenging av barn med støt mot hodet.

Tingrettens dom ble 90 dager betinget fengsel.

Påtalemyndigheten anket til lagmannsretten (LB-2015-80505) over straffutmålingen, og domfelte anket over skyldspørsmålet.

De sakkyndige forklarte i lagmannsretten at mulige årsaker til hjernehinneblødningen er fall fra stor høyde, kraftig risting eller annen skademekanisme med tilsvarende stor kraftpåvirkning, for eksempel slenging av barnet med støt med hodet mot underlag som ikke har gitt ytre skader. Det ble ikke funnet skjelettskader.

Skadene i saken oppfylte ikke de medisinske kriteriene for shaken baby syndrome fordi det ikke forelå hjernevevsskade og fordi øyebunnsblødningen ikke kunne anses som en følge av voldsut øvelsen. I denne saken førte altså de manglende kriteriene i SBS-triaden til at det ikke ble vurdert som en SBS-skade. Lagmannsretten konstaterer at barnet hadde vært «utsatt for en kraftanvendelse av slik styrke at den er straffbar». Domfellelsen gjaldt altså legemsfornærmelse med skade til følge under særdeles skjerpende omstendigheter, jf. strl. 1902 §228, jf. § 232.

Lagmannsretten skriver at uavhengig av om barnet hadde vært utsatt for et tidligere traume, legger lagmannsretten på denne bakgrunn til grunn at barnet i løpet av siste én til tre døgn forut for at det ble undersøkt, hadde vært utsatt for en kraftanvendelse av slik styrke at den er straffbar, dersom det er utvist tilstrekkelig grad av skyld. Lagmannsretten fant det bevist ut over rimelig tvil at tiltalte utsatte barnet for forsettlig legemsfornærmelse.

Lagmannsretten la etter en gjennomgang av rettspraksis til grunn at det for legemsfornærmelser i form av risting av små barn eller lignende karakter, gjelder et betydelig høyere straffenivå enn det som er kommet til uttrykk i den generelle redegjørelsen i Prop. 97 L (2009-2010). Straffen i

lagmannsretten ble derfor satt til fengsel i ett år, hvorav to måneder ble gjort betinget på grunn av tiden som hadde gått, og ytterligere fire måneder ble gjort betinget fordi tiltalte som følge av hendelsen hadde vært underlagt besøksforbud i eget hjem i 11 måneder. Besøksforbudet hadde utvilsomt vært en stor belastning for familien.

Lagmannsretten fant derfor at besøksforbudet hadde vært en så inngripende frihetsinnskrenkning at det på bakgrunn av Høyesteretts praksis om andre typer frihetsinnskrenkninger, var adgang til å ta hensyn til den ved straffutmålingen.

Oppreisningserstatningen til barnet ble satt til 30000 kroner.

Etter en ny analyse av det foreliggende medisinske materialet har de tre medisinerne blant artikkelforfatterne konkludert med at det ses kliniske og radiologiske tegn forenlig med ekstern hydrocefalus, som kan ha forårsaket eller predisponert for subdurale blødninger.

Det ble ikke i dommen lagt til grunn at det forelå filleristing som skadeårsak, men en kraftanvendelse av slik styrke at den er straffbar.

\subsection{Mor dømt for ved flere anledninger å ha mishandlet sin to-tre måneder gamle $\varsigma \varnothing n n$}

En mor ble i tingretten (THEDM-2015-16342) dømt til to års fengsel, hvorav ett år betinget, for brudd på strl. $1902 \S 219$ andre ledd, jf. første ledd. Legemsskaden ble påført blant annet ved filleristing slik at hennes sønn på to-tre måneder fikk blødninger under den harde hjernehinnen. Det ble også påvist andre skader, herunder ribbeinsbrudd. Barnet ble ikke påført varig mén.

I saken uttalte fem sakkyndige seg. De slo fast at barnet hadde såkalt filleristingssyndrom:

Skadene er beskrevet overfor. Blodansamling under den hårde hjernehinne kan skyldes kraftig risting slik at hjernen utsettes for akselerasjon og deselerasjon (bråstopp). Hjernen har myk konsistent og «flyter» i hjernevæsken. Ved slik kraftig akselerasjon og bråstopp kommer samleårer mellom skalletak og hjerne (såkalte brovener) i strekk og kan briste, slik at det samler seg blod under den hårde hjernehinne. 
Hos NN finnes et av de tre tegnene på filleristing, nemlig blødning under den hårde hjernehinne. Dessuten ribbeinsbrudd og muligens bøttehankbrudd som støtter diagnosen filleristing.

I en tilleggsuttalelse presiseres følgende:

Det viktigste mulige alternativ til påført skade med betydelig kraft, er at NN har en tilstand med godartet stor hodeskalle (benign makroemni), forårsaket av godartet infantilt ytre vannhode (benign infantil external hydrocephalus).

En annen av de sakkyndige vurderer saken slik:

Min totale vurdering i saken er at NN IKKE har hatt tilstanden benign infantil hydrocephalus som bidragende årsak til blødningen i hodet.

Den tredje sakkyndige forklarte seg om hvorfor det eventuelt er en årsakssammenheng mellom såkalt ytre godartet vannhode (BEH) og blødning under den harde hjernehinnen.

Retten skriver om denne sakkyndige:

Han har vist til at det er tale [om] bro-vener i strekk som eventuelt kan sprekke, og at dette er omstridt teori.

Skadene på NN er samanfallande med det ein kallar filleristing syndrom (shaken baby syndrome). Retten viser her til forklaringa til [den ene sakkyndige], der han har gjort greie for syndromet: Dersom ein baby blir rista kraftig, vil hjernen, som er mindre enn skallen, utsettes for akselerasjon og deselerasjon (bråstopp).

Retten la således vekt på de aktuelle skadene slik de sakkyndige beskrev dem, og tiltalte ble dømt til fengselsstraff i to år, hvorav ett år betinget. Domfelte anket.

I lagmannsretten (LE-2015-70318) møtte de samme sakkyndige. En av dem redegjorde for at blødningene under den harde hjernehinnen var forenlig med at barnet hadde blitt filleristet.

En av de andre rettsoppnevnte sakkyndige vurderte hvorvidt barnet hadde et ytre godartet vannhode (BEH) da blødningene under den harde hjernehinnen oppsto.

Barnet ble undersøkt da det var to år og to måneder gammelt, og det var ved den undersøkelsen ikke tegn til ytre godartet vannhode. Den sakkyndige bygget sin vurdering på tidligere unders $\varnothing$ kelser av barnet, herunder målinger av barnets hodeomkrets og MR.

Undersøkelsene fant ingen feil ved stoffskiftet, blodlevringen var normal og barnet led ikke av beinskjørhet. Det ble heller ikke avdekket forhold som kunne forklare skadene på en annen måte enn at disse var påført. Det ble videre bemerket at det heller ikke ble avdekket forhold under svangerskapet eller ved fødselen, som kunne forklare skadene.

Den sakkyndige redegjorde for at blødningene under den harde hjernehinnen var forenlige med at barnet hadde blitt filleristet. Som en konsekvens av filleristing vil en baby blant annet kunne bli irritabel, sløv, få oppkast eller redusert matlyst, krampeanfall og få en bananlignende rykning («opistotonus»- med kroppen spent i en bue, slik at bare bakhodet og hæler berører underlaget). Flere av disse symptomene ble observert.

Basert på de vurderingene som den sakkyndige hadde foretatt, fant lagmannsretten trygt å kunne se bort ifra at barnet var født med ytre godartet vannhode, eventuelt at det var årsaken til de aktuelle blødningene.

I den sammenhengen ble det vist til at barnets hode var normalt ved fødselen, at tilstanden BEH er svært sjelden, og at guttens hodeomkrets i så fall ville ha økt jevnt og ikke med et «hopp», slik det gjorde da blødningene senere ble avdekket. Det var på det rene at barnets hode $\varnothing$ kte markant etter et gitt tidspunkt. Sett i sammenheng med de $\varnothing$ vrige skadene framsto det etter lagmannsrettens syn som klart at blødningene er påført ved hodetraumer. 
Straffen i lagmannsretten ble redusert til fengsel i ett år. Oppreisningserstatning ble tilkjent med 150000 kroner.

Etter en ny analyse av det foreliggende medisinske materialet har de tre medisinerne blant artikkelforfatterne konkludert med at det ses kliniske og radiologiske tegn som er forenlige med ekstern hydrocefalus, som kan ha forårsaket eller predisponert for subdurale blødninger. Ut fra denne vurderingen framstår derfor de sakkyndiges vurdering av at BEH ikke forelå, som uriktig.

De sakkyndiges kommentarer om et plutselig hopp i hodeomkretsutviklingen kan forklares fullt ut med funn i en norsk epidemiologisk undersøkelse som viser at barn som utvikler BEH stort sett er født med normal hodeomkrets og at denne øker plutselig og kraftig ved to til tre måneders alder. ${ }^{44}$

\subsection{Far dømt og deretter frikjent for legemsfornærmelse med skadefølge overfor tre måneder gammel sønn}

Far ble i tingretten (TSUHO-2014-196235) dømt for saksforhold som både gjaldt overtredelse av utlendingsloven $\S 108$ andre ledd bokstav a, jf. $\S 55$ for å ha oppholdt seg ulovlig i riket, overtredelse av strl. $1902 \S 228$ første ledd for legemsfornærmelse mot sin samboer og for overtredelse av strl. $1902 \S 390$ for ved skremmende opptreden å ha krenket en annens fred. Han var også tiltalt for å ha påført sin tre måneder gamle sønn blant annet utbredte blødninger på begge sider av hjernen under den harde hjernehinnen, utbredte blødninger i flere lag av netthinnen i begge øyne og utbredt skade på hjernen.

I tingretten var det to rettsoppnevnte sakkyndige som vurderte årsaken til barnets skader:

De sakkyndige i saken er samstemte i at den eneste mulige årsak til skade er at NN er blitt utsatt for kraftig risting (shaken baby syndrome). De viser til medisinske funn som samlet bekrefter dette og utelukker andre mulige årsaker: Forekomst av ferske blødninger under den harde hjernehinnen på begge sider av hodet, omfattende blødninger på begge øyers netthinne og omfattende hjerneskade som følge av forstyrrelser i hjernen som fører til hjertesvikt/pustestans. Skadene oppstår fordi ristingen gjør at barnets hjerne settes i bevegelse inne i hodeskallen.

Straffen i tingretten ble samlet fengsel i to år.

Skyldspørsmålet gjeldende de $\emptyset$ vrige forholdene var endelig avgjort i tingretten, men spørsmålet om filleristing ble behandlet av lagmannsretten etter anke (LG-2015-63748-1).

I lagmannsretten ga de samme to sakkyndige som i tingretten uttrykk for at det var overveiende sannsynlig at det hadde skjedd en filleristing. I tillegg ble enda en sakkyndig oppnevnt av lagmannsretten.

Denne tredje sakkyndige presiserte at grad av sannsynlighet innen rettsmedisin er henholdsvis grad 1, som er helt sikker, og nesten aldri benyttet, grad 2, der det bare er rom for hypotetisk tvil, og grad 3, som er sannsynlig. I denne sak forklarte denne sakkyndige at hans vurdering av sannsynligheten for at det forelå filleristing var noe mellom grad 2 og 3 , og begrunnet dette med fraværet av brudd og blåmerker.

Lagretten besvarte spørsmål om tiltalte var skyldig i legemsfornærmelse mot sin tre måneder gamle sønn og om legemsfornærmelsen hadde hatt til følge betydelig legemsskade med ja. Fagdommerne fant imidlertid enstemmig at det ikke var ført tilstrekkelig bevis for tiltaltes skyld, slik at saken skulle behandles på ny for andre dommere.

Ved den nye behandlingen med meddomsrett i lagmannsretten (LG-2015-63748-2) ble tiltalte etter en konkret vurdering enstemmig frifunnet. Lagmannsretten trengte for sin avgjørelse ikke å ta stilling til hva som var årsaken til skadene.

Hovedproblemstillingen i saken var om tiltalte hadde forårsaket skader på fornærmede ved å riste ham kraftig.

I forbindelse med oppstart av den første ankeforhandlingen i lagmannsretten, meldte en fagkyndig sin bekymring til daværende forsvarer ${ }^{45}$ Han hadde noe kjennskap til saken og mente at skadebildet var forenlig med vannhode (BEH). Også denne fjerde fagkyndige ble oppnevnt av retten som sakkyndig, og han avga erklæring og flere tilleggserklæringer. Underveis hadde Den rettsmedisinske

\footnotetext{
${ }^{44}$ Wiig et al., 2017; Zahl et al., 2019.

${ }^{45}$ Den fjerde sakkyndige var Knut Wester, en av medforfatterne til denne artikkelen.
} 
kommisjon kritiske merknader til denne sakkyndiges vurderinger og konklusjoner. Dette medførte at retten ba om ytterligere sakkyndighet innen radiologi og netthinneblødninger.

Den fjerde sakkyndige konkluderte med

at det foreligger sannsynlighetsovervekt for at fornærmedes hjerneskade skyldes kjente komplikasjoner til godartet ytre vannhode/benign ekstern hydrocefalus (BEH) ...

Blant annet ble det vist til den svenske SBU-rapporten ${ }^{46}$ samt egen ${ }^{47}$ og andres ${ }^{48}$ forskning. Den rettsmedisinske kommisjon fant ikke vesentlige mangler ved tilleggserklæringene, men ga uttrykk for at det i litteraturen ikke var beskrevet noen tilfeller av utbredte spontane blødninger i øynenes netthinner hos barn med BEH, og at konklusjonene i den svenske rapporten var omstridt i det internasjonale fagmiljøet.

Videre skrev Den rettsmedisinske kommisjonen at tilleggserklæringen demonstrerer de faglige utfordringene innen det aktuelle feltet. Ikke minst er det en del usikkerhet knyttet til tolkningen og forståelsen av kliniske funn, operasjonsfunn samt fortolkning av radiologiske funn (MR og CT).

Etter en samlet vurdering fant lagmannsretten ikke grunnlag for å konstatere at tiltalte hadde forårsaket skadene på fornærmede ved å ha handlet som beskrevet i tiltalen, det vil si å bevisst ha ristet barnet så kraftig at dette ble bevisstløst og dermed påført de aktuelle skader. Lagmannsretten fant at legemsfornærmelsen som årsak til skaden var langt unna den grad av sikkerhet som er nødvendig for domfellelse. Den ville hovedsakelig måtte vært basert på at man ikke kjenner noen annen mulig årsak til netthinneblødninger enn kraftig risting, og en slik domfellelse ville ikke være forsvarlig. I dette tilfelle kunne heller ikke kraftig risting i gjenopplivingsøyemed utelukkes. Tvil om årsaken til barnets skader kom tiltalte til gode, og han ble frikjent.

Etter en ny analyse av det foreliggende medisinske materialet har de de to øvrige medisinerne blant artikkelforfatterne konkludert som den fjerde sakkyndige i straffesaken (og medforfatter her) med at det ses kliniske og radiologiske tegn forenlig med ekstern hydrocefalus, som kan ha forårsaket eller predisponert for subdurale blødninger.

\subsection{Far dømt for å ha mistet fem måneder gammel sønn i gulvet, frikjent for filleristing}

En mann ble i tingretten (TJARE-2009-150038) dømt til fengsel i tre år og ni måneder for brudd på strl. $1902 \S 242$ andre ledd, jf. § 243. Han mistet sin fem måneder gamle sønn i gulvet med hodet først. I uken etter uhellet ble barnet sykere uten at faren opplyste om uhellet. Barnet fikk en varig alvorlig hjerneskade etter hendelsen.

Oppnevnt sakkyndig avga tre erklæringer og møtte under tingrettsforhandlingen. Der forklarte den sakkyndige at den sannsynlige årsaken til den første blødningen var filleristing eller stump vold mot hodet. ${ }^{49}$ Selv om det er lite sannsynlig at et fall på i overkant av en meter mot betonggulv med vinylbelegg kan forårsake en slik skade, kunne den sakkyndige ikke helt utelukke dette som årsak. Når det gjaldt den nyeste blødningen og surstoffmangelen i hjernen, forklarte den sakkyndige at den mest sannsynlige årsaken til dette var filleristing eller ny stump vold mot hodet. Han kunne likevel ikke helt utelukke at dette var en følgeskade av den første blødningen.

Tingretten la derfor til grunn at den eldste blødningen ble forårsaket av at tiltalte mistet sønnen i gulvet som gjengitt ovenfor. Den andre blødningen med komplikasjoner var en følgeskade av den første. Far ble altså ikke dømt for filleristing, men for å ha hensett barnet i hjelpeløs tilstand, jf. strl. $1902 \S 242$.

\footnotetext{
${ }^{46}$ SBU, 2016.

${ }^{47}$ Wiig et al. 2017; Zahl et al. 2019.

${ }^{48}$ P. D. McNeely et al., «Subdural Hematomas in Infants with Benign Enlargement of the Subarachnoid Spaces Are Not Pathognomonic for Child Abuse», AJNR Am J Neuroradiol, vol. 27, 2006, s. 1725-1728 og D. Miller, P. Barnes og M. Miller, «The significance of macrocephaly or enlarging head circumference in infants with the triad further evidence of mimics of shaken baby syndrome», Am J Forensic Med Pathol., vol. 36, 2015, s. 111120.

49 TJARE-2009-150038.
} 
Også i lagmannsretten (LG-2010-51588) ble han domfelt etter straffeloven § 242 andre ledd, jf. $\S 243$, for å ha hensett barnet i hjelpeløs tilstand. Straffen ble fengsel i tre år, hvorav ett år og seks måneder på vilkår.

Etter en ny analyse av det foreliggende medisinske materialet har de tre medisinerne blant artikkelforfatterne konkludert med at det ses kliniske og radiologiske tegn forenlig med ekstern hydrocefalus, som kan ha forårsaket eller predisponert for subdurale blødninger. Fall på én meter er tilstrekkelig til å gi slik skade, kanskje sett i sammenheng med en allerede eksisterende BEH.

Straffegrunnlaget var ikke basert på bedømming av årsaken til guttens medisinske situasjon, men av manglende oppfølging fra farens side.

\subsection{Far dømt for legemsbeskadigelse med $d \varnothing$ den til følge overfor tre og et halvt år gammel $s ø n n$}

Far ble i tingretten (TRANA-2014-184055) dømt til åtte års fengsel for legemsbeskadigelse med døden til følge, samt flere tilfeller av vold mot egne barn. Hans tre og et halvt år gamle sønn døde av hodeskader. Retten var ikke i tvil om at det var faren som hadde påført gutten skadene. Han ble i tillegg dømt til å betale oppreisningserstatning til tre av sine barn med 125000 kroner hver, og oppreisningserstatning på 215000 kroner til sin ektefelle.

Den sakkyndige uttalte i tingretten:

Blødninger mellom hjernens overflate og skallebena oppstår vanligvis etter kraftig traume mot hodet, fall fra høg høyde eller hos mindre barn etter filleristing (vanligst hos barn $<1 \frac{1}{2} 2$ års alder).

Det ble ikke funnet tegn til kraniebrudd eller blødninger i øynene, spesielt netthinneblødninger. Barnet veide $16 \mathrm{~kg}$, og det er meget uvanlig at et barn med denne vekten kan bli filleristet med subdural- og $\varnothing$ yebunnsblødninger som resultat. Sakkyndige utelukket nærmest at sønnen B hadde fătt sine hodeskader av filleristing. Hodeskadene var mer sannsynligvis påført ved kraftig stump vold mot hodet en eller flere ganger av en voksen person.

Ved ankebehandlingen (LH-2015-85962) ble tiltalte dømt til fengsel i ni år for overtredelser av strl. $1902 \S 229$ tredje straffalternativ, jf. § 232, og strl. 1902 § 219. Lagmannsretten kunne ikke se at det ville ha betydning for straffverdigheten hvordan den stumpe volden ble utført. Skaden som ble påført ved kraftig stump vold var indre blødning i hodet, nærmere bestemt ca. 1 desiliter blod innenfor skallen, utenfor hjernen. Filleristing ble tatt ut som mulig skadeårsak i tingretten og er ikke nevnt i lagmannsrettsdommen.

Lagmannsretten bygget i sin vurdering av omfanget i det vesentlige på ektefellens forklaring, opplysninger framkommet i dommeravhør av de øvrige barna sammenholdt med vitneforklaring fra de to eldste barnas beredskapsmor, den sakkyndiges forklaring og bilder som viste arr og sår på barna. Dette gjelder forklaringer om ulike voldshendelser, trusler og andre krenkelser. Disse forklaringer støttes også opp av barnas atferd så vel under avhørene som i beredskapshjemmene.

Tiltalte slo de fire guttene, og volden kunne skje flere ganger i uka ifølge ektefellens politiforklaring. I tillegg til at han kunne slå med flat hånd, brukte han også forskjellige gjenstander å slå med, blant annet et langt skohorn av metall, en ledning og et belte. Barnas mor kunne også fortelle at tiltalte ved en anledning dunket hodet til den ene sønnen i gulvet.

At tiltalte, og da for første gang under tingrettens behandling, erkjente tre-fire voldshendelser mot to av barna, kunne heller ikke føre til noen strafferabatt.

I denne saken ble filleristing utelukket av den sakkyndige i tingretten, framfor alt på grunn av den døde guttens alder.

Oppreisningserstatning ble tilkjent med 125000 kroner til fire fornærmede og i tillegg ble mor til avdøde/tidligere ektefelle tilkjent 90000 kroner.

Etter en ny analyse av det foreliggende medisinske materialet har de tre medisinerne blant artikkelforfatterne konkludert med at det ses kliniske og radiologiske tegn forenlig med en ubehandlet ekstern hydrocefalus som kan ha forårsaket eller predisponert for subdurale blødninger. Subdurale blødninger kan forårsake krampeanfall. Alvorlige krampeanfall kan føre til sirkulasjonssvikt og respirasjonssvikt, noe som sannsynligvis forårsaket døden. 


\subsection{Far dømt for vold mot fire uker gammel datter}

Far ble dømt i tingretten (TOSLO-2016-113865) til fengsel i åtte år for vold mot sin fire uker gamle datter og for ikke å ha sørget for at hun kom til lege før det var gått ett og et halvt døgn. Datteren overlevde, men hadde fått alvorlige og varige skader. Retten så helt bort fra farens forklaringer for hvordan skaden oppsto. Barnets mor ble dømt for brudd på hjelpeplikten, jf. straffeloven $2005 \S 288$, til en straff av fengsel i ti måneder, hvorav fire måneder ble gjort betinget.

Rettsoppnevnt sakkyndig forklarte i retten at barnet i dette tilfellet har alle de tre typer av hodeskader som er karakteristisk ved såkalt «Shaken baby syndrome» (også omtalt som «shakingimpact syndrome» eller «abusive head trauma»): blodansamling i hjernehinnene, utbredt hjerneskade og blodansamling i øynenes netthinner. Slike skader er beskrevet hos barn som er utsatt for kraftig filleristing, ved at en voksen holder barnet i et grep rundt skuldre eller mageregion og rister barnet kraftig fram og tilbake i minst flere sekunder. Hodet blir dermed utsatt for sterke akselerasjons- og deselerasjonskrefter, hvor hjernen beveger seg inne i hodeskallen på en slik måte at nervetråder ødelegges og blodårer som forbinder hjernen med skallen rives over og forårsaker intrakranielle blødninger. Barnet kan også som følge av blødningene og/eller det påførte traumet få pustestoppepisoder, som igjen kan gi surstoffbetinget hjerneskade. Mange barn som er utsatt for filleristing har også ytre skader som hevelser, blåmerker og bruddskader.

De sakkyndige brukte uttrykket filleristing, og lagmannsretten mente det bevist at også dette uttrykket var dekkende for den kraft som faren brukte.

Retten mener det er bevist utover enhver rimelig tvil at tiltalte utsatte sin datter $\mathrm{C}$ for vold som beskrevet i tiltalebeslutningen post I ved kraftig filleristing og/eller ett eller flere slag mot hoderegionen. Voldsutøvelsen har medført betydelig skade som omfattes av straffeloven $§ 274$ andre ledd.

Saken ble anket til lagmannsretten (LB-2016-172674) som fant det bevist at barnet hadde blitt ristet fram og tilbake med stor kraft og at forsettet til domfelte omfattet betydelig skade, jf. straffeloven $2005 \S 274$ andre ledd.

Straffen for far ble den samme som i tingretten, åtte års fengsel. Barnets mor ble i lagmannsretten dømt for brudd på hjelpeplikten, jf. strl. 2005 § 288, til en straff av fengsel i ti måneder, men slik at fullbyrdingen ble utsatt for seks måneder.

Far, men ikke mor, anket til HR, som tillot anken fremmet for å prøve straffutmålingen (HR-20171785-U).

I HR-2017-2282A framgår at det ikke foreligger praksis fra Høyesterett om risteskader på spedbarn, men det er en rekke ting- og lagmannsrettsdommer om dette. Gjennomgående er tiltalte i de dommene dømt for legemsfornærmelse med skade til følge, hvor forsettet ikke har omfattet skadefølgene. Dommene er fra både før og etter straffskjerpelsen i 2010, og straffen har stort sett ligget mellom ett og to års fengsel. ${ }^{50}$ Høyesterett konstaterer:

(26) Karakteristisk for ristesakene er at skaden skjer på få sekunder, skyldes frustrasjon hos tiltalte, og at gjerningspersonen ofte ikke har noe egentlig ønske om å skade barnet og nok i noen tilfeller heller ikke skjønner hvor farlig det er med slik «filleristing».

(27) I vår sak var det likevel et svært lite barn og det ble brukt stor kraft. Det var tilfeldigheter som gjorde at barnet ikke døde. Forsettet er funnet å omfatte meget betydelig skade, herunder at barnet ble påført hjerneskade.

Straffen for overtredelse av straffeloven $2005 \S 274$ andre ledd og $\S 288$ ble av Høyesterett, i dette tilfelle, fastsatt til fengsel i syv år.

Av sykehusets journaler framgår at barnet sov sammen med moren da moren angivelig snudde seg $\mathrm{i}$ sengen tidlig om morgenen (kl. 06.00) og traff datteren i venstre tinning med sin albue. Etter det var

\footnotetext{
${ }^{50}$ Se våre eksempel under 4.4, 4.6, 4.8 og 4.14.
} 
barnet slapt og ville ikke spise. Ved innleggelse i sykehus 15 timer seinere var hun våken og ga blikkkontakt, men ble beskrevet som «sløv/trøtt» og den store fontanellen var spent, tydende på forhøyet intrakranialt trykk. «CT-undersøkelse neste morgen (15 timer etter slaget mot venstre tinning) viste fersk hjernehinneblødning og blod under den harde hjernehinne (akutt subduralt hematom)». Likeledes viste denne unders $\emptyset$ kelsen at hjernebarken og underliggende hjernevev i store deler av storhjernen, men ikke de dypereliggende hjernestrukturer, var ødelagt på begge sider. I tillegg til hjerneskaden hadde dette barnet et kragebeinsbrudd - slike brudd er langt det hyppigste fødselsrelaterte brudd.

Etter en ny analyse av det foreliggende medisinske materialet har de tre medisinerne blant artikkelforfatterne konkludert med at dette barnet har radiologiske funn tydende på en utbredt hjerneskade, forenlig med manglende blodtilførsel til storhjernen. Man kan dermed ikke utelukke at tilstanden er forårsaket av en spontant oppstått medisinsk tilstand.

\section{Enkelte aspekter fra barnevernssaker}

\subsection{Innledning}

I tillegg til straffesakene der vi har foretatt en gjennomgang av pådømte saker i perioden 2004-2015, har spørsmålet om filleristing også vært reist i saker vedrørende foreldreansvar og hvem barnet skal bo fast hos etter barneloven, eventuelt for å gi grunnlag for inngrep fra barnevernet overfor foreldrene etter barnevernloven (bvl.).

Disse sakene ble funnet ved det samme søket som for straffesakene, og to sentrale saker tas opp her. I ingen av sakene foreligger medisinske vurderinger foretatt i samband med vårt prosjekt.

Framstillingen er derfor utelukkende basert på de refererte rettsavgjørelsene.

Sakene belyser hvor forskjellig beviskravet er i barnevernssaker i forhold til de gjennomgåtte straffesakene.

\subsection{Omsorgsovertakelse og begrenset tilsyn på grunn av filleristing av gutt ved seks måneders alder}

I en barnevernssak behandlet i tingretten (TINDE-2002-00583 A) var det en bakenforliggende mistanke om filleristing. I tingretten uttalte den sakkyndige at det var overveiende sannsynlig at «risting av typen Shaken Baby Syndrome» var årsaken til de påviste skadene på barnet. En slik skade må være påført av andre.

Saken hadde tidligere vært vurdert strafferettslig. Påtalemyndigheten henla straffesakene mot foreldrene etter bevisets stilling. Anmeldelsen gjaldt grov legemsbeskadigelse, strl. $1902 \S 231$.

Tingretten kom til at vilkårene for omsorgsovertakelse etter bvl. § 4-12 første ledd bokstav a og c var til stede.

I likhet med fylkesnemnda og tingretten kom også lagmannsretten (LF-2003-1480) til samme resultat. Det ble lagt til grunn at barnet da det var seks måneder var blitt mishandlet og påført shaken baby syndrome. Lagmannsretten anfører at det er overveiende sannsynlig at barnets alvorlige skader skyldes at han er blitt ristet med stor styrke og intensitet.

Retten mente videre at det forelå en generell og alvorlig omsorgssvikt. Samvær med foreldrene ble begrenset ut fra at barnet skal holde seg kjent med sitt biologiske opphav, men det ble ansett nødvendig med tilsyn under samvær.

Ifølge uttalelse fra sakkyndig, den samme som i tingretten, gir guttens balanse- og motoriske problemer - han begynte å gå først ved 22-måneders alder - og innadvendt tommel, klar mistanke om hjerneskader som er forenlig med skader etter shaken baby syndrome. Den sakkyndige uttalte videre at det ikke behøvde å være mer enn ett tilfelle av risting, men kunne heller ikke utelukke at det kunne være flere tilfeller.

Anke til Høyesterett ble nektet fremmet.

\subsection{Barnevernssak om filleristing etter henlagt straffesak. Tvangsadopsjon}

Omsorgen for en gutt på to måneder ble fratatt foreldrene på grunn av at det ble konstatert at han hadde livstruende hodeskader (TOSLO-2015-126023/LB-2016-49371). Det var mistanke om at han 
var utsatt for filleristing. Etter en operasjon i hjernen ble han plassert i beredskapshjem og deretter i fosterhjem.

Straffesaken mot foreldrene ble henlagt fordi det ikke var mulig å finne ut hvem av dem som hadde påført gutten skadene.

De medisinske funnene så langt peker i retning av at skadene (blodansamlingene under den harde hjernehinne og blødningene i øyebunnen) skyldes påført skade ved kraftig filleristing.

Samtidig uttrykte retten noe tvil:

Det er mulig at barnet har vært utsatt for kraftig filleristing, men det kan også dreie seg om stump vold mot hodet som ved for eksempel fall fra høyde.

Så konstateres det at

... ingen av de tre sakkyndige oppfattes å ha konkludert med at det er sikkert det er filleristing som er årsaken, og at sannsynlighetsgraden de tre har konkludert med, ikke er den samme.

I dommen siteres følgende uttalelse fra statsadvokatembetet:

I likhet med politiet legger jeg til grunn at det kan føres bevis for at barnet ble utsatt for minst ett tilfelle av «filleristing» i nær tid forut for innleggelse ved AHUS [...] og dette har forårsaket barnets skader. I den forbindelse vises det til tre sakkyndige erklæringer avgitt i anledning saken. Videre mener jeg at det kan føres bevis for at det er en av foreldrene (altså de siktede) som har påført barnet skadene. Det er imidlertid vanskelig, slik jeg vurderer bevisene, å konstatere hvem av foreldrene som har filleristet barnet og dermed påført skadene.

Foreldrene krevde gutten tilbakeført til seg da han var to og et halvt år. Da lagmannsretten behandlet saken, var han fire år. Tilbakeføringskravet ble avslått, jf. bvl. § 4-21, og det ble samtidig gitt samtykke til at fosterforeldrene skulle kunne adoptere barnet, jf. bvl. § 4-20 tredje ledd.

Lagmannsretten fant det vanskelig i barnevernssaken å konkludere på annen måte enn statsadvokaten, nemlig at en av foreldrene hadde påført barnet hode- og øyeskadene. Lagmannsretten la til grunn at selv om filleristing ikke er like farlig nå når gutten er blitt fire år gammel, vil det som har skjedd være en indikasjon på at det er risiko for annen type vold. Av den grunn vil påføring av hodeskaden være en del av vurderingen etter bvl. § 4-20 tredje ledd bokstav a om at foreldrene «varig ikke vil kunne gi barnet forsvarlig omsorg».

Dette var noe av bakgrunnen for at totalsituasjon tilsa at foreldreansvaret ble fratatt foreldrene, og fosterforeldrene fikk samtykke til å adoptere gutten.

\subsection{Noe nærmere om beviskravet for voldspåføring i barnevernssaker}

Det er grunnlag for omsorgsovertakelse etter bvl. § 4-12 første ledd bokstav c «dersom barnet blir mishandlet eller utsatt for andre alvorlige overgrep i hjemmet». Bestemmelsen er et ledd i statens plikt til å beskytte barn mot alle former for mishandling og sørge for en faktisk beskyttelse gjennom omsorgsovertakelse og flytting fra hjemmet. I Ot.prp. nr. 44 (1991-1992) Om lov om barneverntjenester $\mathrm{s} .110$ framgår at bestemmelsen gjelder «når foreldrene gjør seg skyldig i barnemishandling eller andre alvorlige (fysiske) overgrep i hjemmet». Også psykisk mishandling omfattes. Voldsbruk faller også inn under bvl. § 4-12 første ledd bokstav a om «alvorlig omsorgssvikt», se punkt 6.2.

Det er et annet beviskrav i saker om vold mot barnet og inngrep etter barnevernloven enn i straffesaker. Ved vurderingen av årsaksforholdet skal det i utgangspunktet legges vanlig sannsynlighetsovervekt til grunn for at de forhold som utgjør inngrepsgrunnlaget, faktisk foreligger. Det står lite om beviskravet i forarbeidene, men spørsmålet om beviskravet er reist i Rt. 2004 s. 1046. Saken gjaldt samvær, men det antas at uttalelsen om beviskravet har gyldighet også for omsorgsovertakelse. I dommen ble det uttalt at: 
Det kan ikke stilles opp et strengere beviskrav enn vanlig sannsynlighetsovervekt for å kunne legge til grunn at skade skyldes en eller annen form for mishandling fra en eller begge av foreldrenes side. De hensyn som tilsier et skjerpet beviskrav for belastende forhold, for eksempel erstatningssaker eller forsikringssaker, gjør seg ikke gjeldende i denne type saker.

Tilsvarende framgår av NOU 2016: 16 Ny barnevernslov - Sikring av barnets rett til omsorg og beskyttelse under framstillingen av gjeldende rett (punkt 11.9.1). Her stadfestes at beviskravet etter § 4-12 første ledd bokstav a til c «er alminnelig sannsynlighetsovervekt», mens bokstav d oppstiller et skjerpet beviskrav, idet det må være «overveiende sannsynlig» at barnet vil bli utsatt for skade.

Snarere kan det reises spørsmål om beviskravet er noe svakere enn sannsynlighetsovervekt dersom det foreligger fare for alvorlig skade. I Rt. 2014 s. 976 (avsnitt 44) viste førstvoterende til forarbeidene til nylig vedtatte endringer i barnelova og uttalte at følgende uttalelse i Ot.prp. nr. 103 (2004-2005) Om lov om endringer i barnelova mv. (omfang av samvar, styrking av meklingsordningen, tiltak for å beskytte barn mot overgrep, foreldreansvar etter d $\phi d s f a l l$, tilbakebetaling av barnebidrag $m v$.) s. 56 også hadde overføringsverdi til vurderinger om samværsnekt etter barnevernloven:

Hensikten med tilføyelsen er videre å sikre at hensynet til barnet tillegges tilstrekkelig vekt i de situasjonene hvor det er vanskelig eller umulig å ta stilling til om overgrep har skjedd eller vil komme til å skje. Hvis det er en reell risiko for at barnet blir utsatt for overgrep hos en av foreldrene, må dette få betydning for rettens avgjørelse. Det kan ikke legges vekt på enhver påstand om overgrep. Det må legges til grunn at det som et utgangspunkt må foreligge forhold som underbygger påstanden. Det kan ikke kreves sannsynlighetsovervekt for at mistanke om vold og overgrep skal legges til grunn. Det vil også kunne være tilstrekkelig med en mindre grad enn 50 prosent sannsynlighet for at beviskravet kan anses oppfylt. Hvilken grad av sannsynlighet som må foreligge vil avhenge av de konkrete omstendighetene i saken, hvor forhold som arten av overgrep det er fare for, alvorlighetsgrad og personlige forhold hos de involverte kan få betydning. Dersom det er en risiko for alvorlige overgrep, vil det kunne tilsi at det skal mindre til for at beviskravet anses oppfylt.

Tilsvarende beviskrav - sannsynlighetsovervekt eller endog svakere ved mistanke om vold og overgrep - vil også gjelde der det foreligger mistanke om vold i form av filleristing, og dette legges tydeligvis også til grunn i rettspraksis.

Dette innebærer at selv om foreldrene er frifunnet i straffesak - etter bevisets stilling - om voldsbruk mot barnet, vil det i en etterfølgende barnevernssak være tilstrekkelig for alvorlige inngrep i familielivet at handlingene er tilstrekkelig sannsynliggjort ut fra «de konkrete omstendighetene i saken, hvor forhold som arten av overgrep det er fare for, alvorlighetsgrad og personlige forhold hos de involverte kan få betydning». Dette var tilfellet i sakene referert i 5.2 og 5.3.

Dette begrensede materialet gir ikke grunnlag for generelle vurderinger av bevisvurderingen $\mathrm{i}$ barnevernssaker der det har foreligget mistanke om eller påstått filleristing. Heller ikke er de medisinske bevisene i våre to saker ettergått av de medisinskkyndige medforfatterne. Men beviskravet er altså helt annerledes i barnevernretten der et viktig hensyn er å forebygge framtidige skader, enn $\mathrm{i}$ strafferetten der begåtte straffbare handlinger skal retteføres og der eventuell tvil skal komme tiltalte til gode.

\section{Oppsummerende vurderinger}

\subsection{Et juridisk perspektiv}

Det er gjennomgående i disse sakene at bevisbildet er meget begrenset. I de lagmannsrettssakene som er blitt avgjort av lagretten er det umulig å vite hva lagretten har lagt vekt på av de framlagte bevisene. Uansett er det sjelden eller aldri vitner til selve skadepåføringen. Den antatte gjerningspersonen har som regel vært alene med barnet. I noen meget få saker har far tilstått de faktiske omstendighetene, men ikke strafferettslig skyldansvar. Barnet, i de tilfeller det overlever, er så lite at det ikke selv kan gi noen forklaring. I en sak, 4.17, har øvrige søsken blitt hørt hva gjaldt fars voldsregime. I den saken, 
som er et unntak, ble også ektefellen og en beredskapsmor hørt. I noen saker foreligger innkomstjournaler eller andre medisinskfaglige vurderinger av spesialister innen radiologi, øyeleger eller barneleger. De bærende bevisene i disse sakene er som regel begrenset til konstatering av fysiske skader, så som ytre eller indre hodeskader, ribbeinsbrudd og beinbrudd i tillegg til rettsmedisiners tolking av skadene. Dette berører det generelle temaet om sakkyndiges vekt i rettspleien. Siden vekten, i mangel på andre bevis, er tung, er det «meget viktig at de som blir oppnevnt som sakkyndige, både er kyndige og upartiske. ${ }^{51} \mathrm{Og}$, vil vi tilføye, er vitenskapelig oppdatert. Et annet tema, som vi heller ikke kommenterer nærmere, er om de sakkyndige skal være rettsoppnevnte eller partsoppnevnte. ${ }^{52}$ Uansett, retten er i disse sakene avhengig medisinsk kompetanse som kan bistå med en vurdering av skadenes opprinnelse.

Ved SBS-saker, slik tilfellet er også innen annen sakkyndighet, er det en kompliserende faktor at det forekommer ulike «skoler» og teorier vedrørende vurderingen av faktum. Det er nå reist spørsmål om triadens robusthet som forklarende teori. Så vel den svenske SBU-rapporten, som de forannevnte svenske avgjørelser fra HD, viser dette. Norman Guthkelch, som i sin tid formulerte selve triadehypotesen, skriver nå: «We need new research on the pathology rather than a vain repetition of hypotheses. In obtaining a better understanding of the pathology, such research will assist in the earlier diagnosis and treatment of sick or injured children; it will also serve the cause of justice.» ${ }^{53}$ Riktige domfellelser i saker der retten baserer seg på ekstern fagkyndighet, er avhengig av en konsistent fagkyndighet der konsensus er vitenskapelig dokumentert.

Gjennomgangen av våre straffesaker og enkelte barnevernssaker der filleristing er en del av bakgrunnen for etterfølgende inngrep, viser at det som regel er mer enn én sakkyndig som vurderer skadene. I mange tilfeller skjer dette med bistand fra andre spesialiteter enn rettsmedisin. Men de sakkyndige er ofte gjengangere gjennom hele prosessen fra undersøkelser på sykehuset til straffesak gjennom flere instanser, se punkt 6.3.

Den såkalte triaden blir nevnt første gang i 2005. Deretter vises det regelmessig til de tre kjennetegnene i denne ved vurderingen av om barnet har blitt utsatt for filleristing med shaken baby syndromet som resultat.

Triaden slår dog begge veier. Hvis alle tre kjennetegnene foreligger, heller det i retning av en konklusjon om at barnet har blitt filleristet. Det konkluderes altså fra skadens art til skadens årsak, også når øvrig bevismateriale ikke foreligger.

Men om ett kriterium mangler, så utelukker det i utgangspunktet filleristing som årsak til påviste skader dersom ikke bevisbildet for øvrig skulle tilsi dette. Tiltalte kan like fullt dømmes for voldsutøvelse ut fra bevisgrunnlaget, men ikke for at dette har skjedd ved filleristing.

Bare i noen få av våre straffesaker har domfellelse vært basert utelukkende på forekomsten av triaden. I de aller fleste sakene har barnet også andre skader som blåmerker og ribbeinsbrudd.

I flere saker uttrykker de sakkyndige tvil: «En mulighet for at barnet er blitt utsatt for kraftig filleristing, men at det ikke kan utelukkes at skaden kan ha skjedd fra et fall», og «Det er mulig at barnet har vært utsatt for kraftig filleristing, men det kan også dreie seg om stump vold mot hodet som ved for eksempel fall fra høyde».

I enkelte saker har retten konstatert at barnet har blitt filleristet, men ut fra en foreliggende tvil om hvem av omsorgspersonene som har utøvet volden, er ingen blitt domfelt.

I noen få saker, fra senere tid, har en sakkyndig lansert en alternativ hypotese til skadenes oppkomst, «forårsaket av godartet infantilt ytre vannhode (benign infantil external hydrocephalus)». Dette ble avvist av lagmannsretten som mente at i den ene saken (4.14) kunne retten se bort ifra at barnet ble født med ytre godartet vannhode.

\subsection{En medisinsk gjennomgang}

\footnotetext{
${ }^{51}$ J. Andenæs, Norsk straffeprosess. Samlet utgave ved Tor-Geir Myhrer, 4. utg., Oslo 2009 s. 223.

${ }^{52}$ U. Stridbeck, P. Grøndahl og C. Grønnerød, «Expert for whom? Court-appointed versus party-appointed experts», Psychiatry, Psychology and Law, 2016 23(2) s. 246-255.

53 Se fotnote 37.
} 
De tre medisinerne blant artikkelforfatterne har foretatt nye analyser av det foreliggende medisinske materialet vedrørende de 17 barna med hode/hjerneskade som falt innenfor unders $\varnothing$ kelsen (4.2 til 4.18). Deres funn kan oppsummeres slik. ${ }^{54}$

- De radiologiske unders $\varnothing$ kelsene av barna viser flere ulike typer funn. Hos tre barn (sak 4.2, 4.5, 4.9) foreligger det brudd på skallen i tillegg til funn innenfor skallen. Slike brudd er som regel forårsaket av skade/traumer mot hodet. Hos fem barn (sak 4.4, 4.7, 4.10, 4.12, 4.18) ses omfattende alvorlige skader i hjernevevet, men ingen tegn til brudd på skallen. Ett av disse barna (sak 4.18) har andre kliniske funn som kan forårsakes av traumer. Hos åtte av barna (sak 4.3, 4.8, $4.11,4.13,4.14,4.15,4.16,4.17$ ) foreligger blødninger under den harde hjernehinnen (subdurale blødninger) samt tegn på ekstern hydrocefalus. Tre av disse barna (sak 4.3, 4.11, 4.14) hadde andre kliniske funn som kan forårsakes av traumer. Ett av barna (sak 4.17) ble syk med kramper og fallskader. Hos ett barn (sak 4.6) ses bare blødninger under den harde hjernehinnen. Denne variasjonen i de radiologiske funnene illustrerer vanskelighetene ved å kunne trekke slutninger om årsaker fra enkle kriterier. En mer nyansert analyse av hvert enkelt tilfelle kan eventuelt føre til at man tolker funnene som annet enn filleristing.

- Med to unntak var alle barna i materialet seks måneder eller yngre. ${ }^{55}$ Unntakene var en 15 måneder gammel jente med rakitt («engelsk syke») og utbredte hjerneinfarkter (sak 4.9) og en tre og et halvt år gammel gutt med kliniske og radiologiske funn forenlig med ekstern hydrocefalus (BEH), som ikke ble oppdaget mens han var i live (sak 4.17). For de 15 spedbarna (under et år) som angivelig var filleristet, var alle i første halvdel av første leveår med en gjennomsnittsalder på to og en halv måned.

- Det var en tydelig kjønnsforskjell i materialet ved at det omfattet elleve gutter (65\%) og seks jenter $(35 \%) .^{56}$

- I vårt materiale er det ingen spedbarn eldre enn seks måneder som er vurdert som filleristet av de første sakkyndige.

- Åtte barn hadde kliniske og radiologiske funn som var forenlig med ekstern hydrocefalus (BEH), som kan ha forårsaket eller predisponert for subdurale blødninger. Ett av disse barna var tre og et halvt år, de andre var spedbarn, dvs. under ett år. Alle disse var gutter og gjennomsnittsalderen for spedbarna var 2,9 måneder ( 0,5 til 5 måned; median 2,5 måned).

- Den høye andel av gutter $(100 \%)$ blant de barna som hadde funn forenlig med ekstern hydrocefalus $(\mathrm{BEH})$ er påfallende lik den som ble funnet i en norsk populasjonsbasert studie over forekomst av $\mathrm{BEH}$ hos spedbarn $(86,4 \%) .{ }^{57}$ Likeledes samsvarer den meget lave alderen $\mathrm{i}$ vårt materiale godt med alderen for når BEH har utviklet seg og blitt symptomatisk i den samme norske spedbarnspopulasjonen. ${ }^{58}$ Dette styrker en antakelse om at disse barna kan ha hatt en medfødt tilstand (BEH) som er blitt feildiagnostisert som SBS. ${ }^{59}$

- Seks spedbarn, fire jenter og to gutter, alle seks måneder eller yngre (gjennomsnittsalder 2,1 måned), hadde kliniske og radiologiske funn forenlig med en utbredt hjerneskade, slik man kan se etter oksygenmangel eller manglende blodtilførsel til hjernen eller deler av denne. Man kan hos disse ikke utelukke at tilstanden er forårsaket av en spontant oppstått medisinsk tilstand. I ett av disse tilfellene (sak 4.5) var det samtidig en skallefraktur som tyder på et gjennomgått traume.

- Den meget lave alderen for alle spedbarn i materialet er påfallende og indikerer også en mulig sammenheng mellom funn og symptomer og fødselsrelaterte skader.

\footnotetext{
${ }^{54}$ Forfatterne planlegger en medisinsk vinklet artikkel som vil gå dypere inn i de medisinske funnene.

55 Kripos' datamateriale vedrørende voldsom ristning av 17 barn viser at i åtte av sakene var barnet to måneder eller yngre og i 15 av sakene var barnet fem måneder eller yngre. Kriposrapport, Alvorlig vold mot små barn, september 2019, s. 20.

${ }^{56}$ I Kripos’ datamateriale var det nær dobbelt så mange gutter som jenter, Kripos 2019, s. 20.

57 Wiig et al. 2017.

${ }^{58}$ Zahl et al. 2019.

${ }^{59} \mathrm{~K}$. Wester, «Two infant boys misdiagnosed as «shaken baby», and their twin sisters: A Cautionary Tale», Pediatr Neurol, 2019, 97, s. 3-11.
} 


\subsection{Samlet og avsluttende vurdering}

Et av utgangspunktene for vår undersøkelse, og vårt ønske om å ettergå straffesakene om «filleristing», er den tvilen som i det internasjonale fagmiljøet har kommet til uttrykk om sammenhengen mellom skademekanismen filleristing og skadefølgen SBS. Dette gjelder også ved den triaden av skadefølger som er lagt til grunn som typiske nettopp for filleristing.

Vår gjennomgang viser at det kan være avsagt uriktige dommer på dette grunnlaget, selv om disse isolert sett ikke er mange. Sak 4.8 kan framstå som et eksempel hvor ny medisinsk analyse synes å tilsi at den sakkyndige vurderingen ikke er riktig.

I tillegg synes det å være tvil når det gjelder skadeårsak og skadepåføring i flere andre saker.

I sak 4.14 ble det tatt eksplisitt opp i dommen muligheten for om BEH - og ikke SBS - var årsaken til hjerneskaden. Retten fant like fullt at skadeårsaken utvilsomt var filleristing. Ikke desto mindre anfører de tre medisinske medforfattere at dommen kan være basert på uriktig medisinsk faktum ved at det nettopp synes å foreligge BEH. Ved enkelte dommer $(4.11,4.15)$ er det lagt vekt på at foreldre ikke søkte legehjelp i tide, og derved tas det i dommen ikke stilling til selve mekanismen bak barnets skade.

At flere av sakene har dissenser $(4.6,4.8,4.10)$, kan være et uttrykk for at så vel bevisvurderingen som straffutmålingen i disse sakene er vanskelig.

Samlet sett er som regel de bærende slutningene i straffesakene basert på vurderinger og konklusjoner framlagt av de sakkyndige. Dette er som regel vanskelig for retten å overprøve. I tilfeller der den sakkyndige har foretatt en beregning eller en analyse som dommeren ikke har fagkunnskap til å kontrollere, må han «sverge til magisterens ord». ${ }^{60}$ Men i de sakene der det foreligger andre bevis i tillegg, vet vi ikke hvilken beviskraft de sakkyndiges vurderinger har hatt. Selv om det gjelder et prinsipp om fri bevisvurdering, kan det legges til grunn at vitnemål fra medisinsk sakkyndige, særlig rettsoppnevnte, i alminnelighet tillegges stor vekt i slike saker.

Fordi de sakkyndiges vurderinger stort sett er avgjørende for skyldspørsmålet, burde man unnvike å benytte samme sakkyndig hele veien fra åstedsunders $\emptyset$ kelse, via unders $\emptyset$ kelse på sykehus til å bli rettsoppnevnt sakkyndig i retten. Fra psykologien vet vi at det generelt er vanskelig å avvike fra et tidlig standpunkt. I forskningen er dette beskrevet som confirmation bias. Innenfor rettspleien viser det seg at «bedømmelsen av tvetydige bevis er delvis bestemt av tidlig utviklede hypoteser». ${ }^{61}$ Fra politietterforskningen er det dokumentert at avgjørelser tidlig i etterforskningsfasen kan skape skylapper videre. ${ }^{62}$ En modell som åpner for second opinion er derfor å foretrekke.

Det å bli tiltalt og dømt for påførte legemsskader av egne (eller andres) barn er svært alvorlig. Det kan resultere i langvarige fengselsstraffer, og i de fleste tilfeller blir også omsorgen fratatt foreldrene, eller den av dem som vurderes som gjerningsperson. Regelmessig gir dette belastninger på familielivet som lett kan ende i skilsmisse, og straffeforfølgelsen får konsekvenser på de fleste andre livsområder.

Det er derfor viktig at i saker der det ikke foreligger et bredt bevismateriale at politi, påtalemyndighet, sakkyndige og domstolene er forsiktige med å utlede fra observerbare skader til skadepåføring og skadepåfører, dvs. en slutning fra virkning til årsak.

Når det er foreldrene som stort sett steller svært små barn, blir de derved som regel ansett som skyldige i voldsutøvelse, og som vårt materiale viser, vil slik skadepåføring kunne føre til lange fengselsstraffer.

Det er derfor viktig at så vel medisinsk sakkyndighet som domstolene er forsiktige med å konkludere om foreliggende voldsutøvelse alene basert på et skadebilde når annet bevismateriale for voldsut $\varnothing$ velse ikke foreligger. Som formulert av Kahneman: «Vi er sikkert tilbøyelige til å tro på det fordi det er blitt gjentatt så ofte, men vi burde tenke gjennom det på nytt». ${ }^{63}$

Som nevnt tidligere ser det ut som om man i Sverige siden 2012 har begynt å tenke nytt vedrørende SBS-diagnostiseringens robusthet og er blitt mer forsiktige med å trekke slutninger ut fra skadebildet

\footnotetext{
${ }^{60}$ J. Skeie, Den norske straffeprosess. Første bind, Oslo 1939, s. 231.

${ }^{61}$ S. Magnussen, Vitnepsykologi 2.0, Oslo 2017, s. 294.

${ }^{62}$ I. Fahsing og K. Ask, «Decision Making and Decisional Tipping Points in Homicide Investigations: An Interview Study of British and Norwegian Detectives», Journal of Investigative Psychology and Offender Profiling 10(2), 2013 s. 155-165.

${ }^{63}$ D. Kahneman, Tenke, fort og langsomt, Oslo 2012, s. 80.
} 
alene. Det er denne faglige usikkerheten - tvil om årsak - som har vokst fram blant annet i Sverige, og som vi har ønsket å problematisere i Norge. 